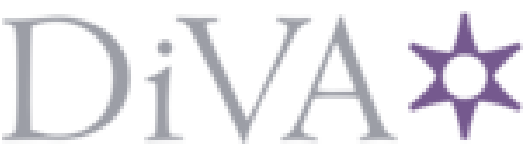

http://www.diva-portal.org

\title{
Postprint
}

This is the accepted version of a paper published in Nature reviews. Molecular cell biology. This paper has been peer-reviewed but does not include the final publisher proof-corrections or journal pagination.

Citation for the original published paper (version of record):

Potente, M., Mäkinen, T. (2017)

Vascular heterogeneity and specialization in development and disease

Nature reviews. Molecular cell biology, 18(8): 477-494

https://doi.org/10.1038/nrm.2017.36

Access to the published version may require subscription.

N.B. When citing this work, cite the original published paper.

Permanent link to this version:

http://urn.kb.se/resolve?urn=urn:nbn:se:uu:diva-341859 


\title{
Vascular heterogeneity and specialization in development and disease
}

\author{
Michael Potente ${ }^{1,2,3} \&$ Taija Mäkinen ${ }^{4}$
}

${ }^{1}$ Angiogenesis \& Metabolism Laboratory, Max Planck Institute for Heart and Lung Research, D61231 Bad Nauheim, Germany

${ }^{2}$ International Institute of Molecular and Cell Biology, 02-109 Warsaw, Poland

${ }^{3}$ DZHK (German Center for Cardiovascular Research), partner site Frankfurt Rhine-Main, D13347 Berlin, Germany

${ }^{4}$ Department of Immunology, Genetics, and Pathology, Uppsala University, Sweden.

\section{Editorial correspondence:}

M. Potente, M.D.

Angiogenesis \& Metabolism Laboratory

Max Planck Institute for Heart and Lung Research

Ludwigstr. 43

61231 Bad Nauheim, Germany

Phone: +4960327051107

FAX: +4960327051104

Email: michael.potente@mpi-bn.mpg.de

T. Mäkinen, Ph.D.

Department of Immunology, Genetics, and Pathology

Uppsala University

Dag Hammarskjölds väg 20

75185 Uppsala, Sweden

Phone: +46184714151

E-mail taija.makinen@igp.uu.se 


\begin{abstract}
Blood and lymphatic vessels pervade almost all tissues in the body and play numerous essential roles in physiology and disease. The inner lining of these networks is formed by a single layer of endothelial cells (ECs), which specializes according to the needs of the tissue it supplies. While the mechanisms of blood and lymphatic vascular development are defined with increasing molecular precision, the processes of endothelial specialization remain largely descriptive. Delineating the principles of vessel type- and organ-specific endothelial differentiation will be critical for understanding how tissues develop and maintain, and how their function becomes abnormal in disease.
\end{abstract}




\section{Introduction}

Organ homeostasis depends on the function of two hierarchically branched networks: the blood and the lymphatic vasculatures. The blood vasculature is a closed circulatory system consisting of arteries, veins, and interconnecting capillaries. It transports gases, nutrients, metabolites, and cells, and provides paracrine signalling molecules to adjacent tissues. The lymphatic system, on the other hand, is blind-ended and unidirectional, and comprises lymphatic vessels, lymph nodes (LNs), and associated lymphoid organs. This 'second vascular system' is coupled to the blood vasculature as it returns extravasated fluid and macromolecules back into the blood circulation. Moreover, lymphatic vessels participate in fat absorption, tissue cholesterol clearance and immune cell trafficking ${ }^{1}$.

Endothelial cells (ECs) line the interior of all blood and lymphatic vessels. In spite of sharing a mesodermal origin and some common functions, these cells are not all-alike. Depending on the type of vessel or organ they reside in, ECs exhibit distinct molecular and functional properties, giving rise to substantial heterogeneity in the vascular tree. The mechanisms by which ECs specialize to fulfil their tissue-specific tasks are poorly understood, yet essential for normal organ development and function. Endothelial specialization has not only been linked to cellintrinsic developmental pathways and transcriptional programmes, but also to signals from the microenvironment. Examples of the latter include growth factors, mechanical forces, metabolic stimuli as well as cell-matrix and cell-cell interactions. In this review, we discuss the molecular and functional heterogeneity within the vasculature and highlight emerging concepts of endothelial specialization. We first provide an overview of the origins and development of blood and lymphatic vessels and then explain how they become remodelled into functionally specialized networks. We also discuss how vessels reciprocally instruct tissue differentiation and function, as well as the mechanisms underlying vessel type- and vascular bed-specific diseases.

\section{Architecture and heterogeneity of the vasculature}

\section{Types of blood and lymph vessels}

Blood vessels organise into tree-like structures. Large arteries carry oxygenated blood away from the heart and branch into smaller calibre arterioles that feed into extensive capillary networks (Figure 1). Venules drain capillaries and converge into larger veins to return oxygen-depleted blood to the heart. Via the pulmonary artery blood is transferred to the lungs for re-oxygenation. Lymphatic vessels are similarly organised into a hierarchy of blind-ended lymphatic capillaries, 
pre-collecting vessels and collecting vessels (Figure 1). Lymphatic capillaries clear excess interstitial fluid and provide an entry site for tissue-resident immune cells into the lymphatic system. By contrast, collecting vessels are specialized for fluid transport, and drain lymph into the thoracic and right lymphatic ducts, which connect to the venous circulation. All of these vessel types have distinctive morphological and functional characteristics (Figure 1).

\section{Heterogeneity in vessel morphology}

Morphological heterogeneity exists at the level of vessel walls and within the network. For instance, the endothelium of arteries and veins forms a continuous monolayer, whereas capillary ECs can be continuous, fenestrated, or discontinuous (Figure 1). Fenestrated endothelium is found in tissues involved in filtration and secretion, including exocrine and endocrine glands, kidney glomeruli as well as the intestinal mucosa, while discontinuous endothelium is characteristic for sinusoidal vascular beds found in the liver and bone marrow ${ }^{2}$. Even within a given capillary network ECs can have distinct characteristics. In the bone vasculature, capillaries close to the growth plate form densely packed column-like structures that control osteoprogenitor cells, while connected sinusoidal capillaries in the bone marrow are highly branched and irregular, and interact with hematopoietic cells ${ }^{3}$. ECs are enwrapped by a basement membrane $(\mathrm{BM})$, whose shape and composition differs across the vascular tre ${ }^{4}$. It varies from a thick elastic lamina in large arteries to a thin, discontinuous BM of lymphatic capillaries (Figure $1)$.

Vessels also differ in their coverage by mural cells (MCs), which comprise vascular smooth muscle cells (vSMCs), pericytes (PCs), and hepatic stellate cells. The walls of larger calibre blood vessels contain vSMCs, which are essential for vascular stability, tone, and blood pressure regulation. Blood capillaries and venules, on the other hand, are encased by PCs. PCs make contacts with the endothelium to regulate vessel stability, transendothelial transport as well as blood-brain barrier (BBB) formation ${ }^{5,6}$. PCs have also been reported to possess contractile properties and contribute to cerebral blood flow regulation ${ }^{7}$, although this finding could not be confirmed in another study ${ }^{8}$ - possibly due to differences in PC definition. MCs have several different embryonic origins in different organs $^{6}$, but whether they also have tissue-specific properties is largely unknown. In the lymphatic system, MC coverage is also different. Collecting lymphatic vessels have a SMC layer that enables lymphatic vessel pumping through its unique ability to undergo phasic in addition to tonic contractions. Lymphatic capillaries lack MC support ${ }^{9}$. Other vessel-type-specific features are luminal valves, which are only present in veins and collecting lymphatic vessels to prevent backflow. 


\section{Heterogeneity in vessel function}

Heterogeneity in morphology is coupled to heterogeneity in function (Table 1). Regulation of vascular tone is an arterial function that occurs primarily at the level of the arterioles, whereas veins, specifically post-capillary venules, are the primary sites of leukocyte extravasation during inflammation. The barrier function of ECs also varies among different vascular beds. In the brain, for instance, ECs establish the highly selective BBB, which protects neurons from toxic molecules, immune cells, and pathogens. Its barrier properties are based on a continuous endothelium that is linked by specialized tight and adherens junctions, low rate of transcytosis as well as the suppression of leukocyte adhesion ${ }^{10}$. The formation and maintenance of the BBB depend on PCs that control EC transcytosis ${ }^{5}$ as well as the expression of MFSD2a, a transporter for select fatty acids whose expression is restricted to BBB ECs ${ }^{11,12}$. Barrier properties of ECs differ dramatically in organs that are involved in absorption and filtering. Examples are kidney and small intestine, in which fenestrated ECs enable the rapid exchange, uptake, and secretion of fluids, solutes, and molecules ${ }^{2}$. Endothelial permeability is even higher in liver sinusoidal ECs (LSECs). LSECs are discontinuous, possess large non-diaphragmed fenestrae organized in sieve plates, and lack organized BM, allowing for passage of small particles from blood to hepatocytes $^{2}$. Interestingly, the barrier properties of blood vessels also influence their niche function. In the bone marrow, the less permeable arteries maintain haematopoietic stem cells (HSCs) in a quiescence state, whereas the more permeable sinusoidal vessels promote HSC activation and differentiation as penetrating blood plasma increases reactive oxygen species formation $^{13}$. Unlike most blood vessels, lymphatic capillaries are tasked with fluid uptake and are thus highly permeable. They are equipped with button-like junctions and anchoring filaments, which together facilitate fluid uptake when interstitial pressure is high ${ }^{1,14}$. In the small intestine, lymphatic capillaries (lacteals) are further specialized for absorption of dietary lipids ${ }^{1}$. Collecting lymphatic vessels instead have continuous 'zipper' junctions ${ }^{14}$, which prevent leakage and ensure the delivery of lymph and dendritic cells (DCs) to LNs. Despite considerable insights into the functions of junctional proteins, still little is known about the composition of endothelial junctions that would explain the barrier properties of different blood and lymphatic vessel types.

Besides permeability, organ-specific vasculature differs in its capacity to deliver nutrients to tissues. In organs with energy-consuming functions, ECs adapt to metabolic demands by adjusting capillary density as well as by controlling endothelial nutrient transfer. The myocardium, for instance, relies on fatty acid (FA) catabolism to produce ATP for its contractile performance and its ECs express high levels of the FA transporter CD36 ${ }^{15}$. Trans-endothelial FA transport has been shown to be regulated by VEGFB, a growth factor that is enriched in 
contractile tissues ${ }^{16}$. However, other studies suggested a primary role for VEGFB in the regulation of cardiac metabolism and vascularization ${ }^{17,18}$. Neurons, on the other hand, rely on glucose as the major energy source. Consequently, BBB ECs preferentially express the glucose transporter GLUT1, which facilitates the transfer of glucose from the blood to the brain ${ }^{10}$. The importance of tissue-dependent trans-endothelial transport becomes evident in disorders in which the expression or function of transporters is compromised. For instance, endothelial GLUT1 levels are decreased in Alzheimer's disease, in response to high-fat diet, and in GLUT1 deficiency syndrome, resulting in reduced brain glucose availability, neuronal dysfunction, and neurodegeneration ${ }^{10,19,20}$. Additional substrate-specific transporters in the BBB endothelium include the solute carrier transporter 7a5 (SLC7A5) that maintains normal levels of branchedchain amino acids (BCAA) in the brain. Its EC-selective inactivation causes autism spectrum disorders $^{21}$.

Functional endothelial heterogeneity is particularly important for regulated trafficking and homing of immune cells. For example, specialized high endothelial venules (HEVs) in LNs express molecules for recruitment and transendothelial migration of lymphocytes ${ }^{22,23}$. Moreover, tissue-specific differentiation of HEV ECs underlies organ-specific homing of leukocytes to distinct anatomical sites. An example is CD22-mediated homing of B cells into gut-associated lymphoid tissue through HEVs expressing ST6Gal I, a glycosyltransferase that generates ligands for $\mathrm{CD} 22^{22}$. Lymphatic vessels are also critically involved in immune cell trafficking into and exit from LNs. For example, lymphatic capillaries express CCL21 chemokine to recruit DCs from the peripheral tissues. Within LNs, specialized LECs in the subcapsular and cortical/medullary sinuses express molecules for the regulated entry of antigens and DCs as well as the egress of lymphocytes, respectively ${ }^{23}$.

\section{Origins and development of the vasculature}

Development and growth of the vasculature are intimately linked to the homeostatic needs of the tissue it serves. A shortage in nutrient and oxygen availability is a primary stimulus to form blood vessels, while increased interstitial fluid pressure is a driver of lymphatic vessel growth in the developing embryo ${ }^{24}$. Depending on the developmental state, vascular bed or (patho)physiological context, blood and lymphatic vessels can form via different mechanisms and from various cellular origins.

\section{Formation of the first blood vessels through vasculogenesis}

The first blood vessels in development form in a process termed vasculogenesis (Figure 2A). In 
zebrafish, the bHLH-PAS protein NPAS4L is at the top of a transcriptional hierarchy that instructs multipotent mesodermal cells to differentiate into endothelial precursors called angioblasts $^{25}$. These angioblasts arise from the posterior and anterior lateral plate mesoderm and assemble into the large axial and cranial vessels as well as the transient pharyngeal arch $\operatorname{arteries}^{26-28}$. The assembly of the axial vessels is coupled to the establishment of the first major artery and vein, the dorsal aorta (DA) and the cardinal vein (CV). Angioblasts were reported first to assemble into a common precursor vessel, followed by the segregation of arterial- and venousfated ECs expressing EphrinB2 and EphB4, respectively ${ }^{29,30}$. More recent studies suggest that arterial and venous ECs are derived from different pools of angioblasts that arise at distinct locations ${ }^{31}$. The existence of additional angioblast pools is also suggested by the observation that loss-of-function mutations of NPAS4L in zebrafish lead to a loss of most but not all ECs ${ }^{25}$.

In mice, the first ECs similarly differentiate from mesodermal progenitors and coalesce into primitive vessel networks at extra- and intraembryonic sites (Figure 2A). NPAS4, the closest mammalian homologue of NPAS4L, is transiently expressed during EC lineage differentiation but is dispensable for mouse embryonic development ${ }^{25}$. The difference between fish and mice might be rationalized by compensation through other bHLH-PAS proteins, but could also point to a predominantly NPAS4-independent pool of angioblasts forming the mammalian vasculature. Irrespective of the precise origins, angioblast differentiation and function is controlled by several tissue-derived factors, including FGF2, BMP4 and VEGF. While FGF2 and BMP4 regulate mesoderm specification and EC differentiation, VEGF appears to have a primary role in EC propagation and survival ${ }^{32}$. Another regulator is the hormonal peptide ELABELA, which guides angioblasts to their proper position in the zebrafish embryo ${ }^{33}$.

\section{Expansion of the blood vasculature through angiogenesis}

Further growth of the embryonic but also the adult vasculature is achieved through angiogenesis. Angiogenesis describes the formation of new vessels from existing ones during which ECs sprout, branch and connect, and subsequently remodel into functional vessel circuits (Figure 2B). This process requires ECs to adopt specialized phenotypes and functions. Leading ECs, the "socalled" tip cells, are migratory and invasive, and are thought to guide new sprouts. Tip cells are followed by stalk cells, which elongate and stabilize the nascent vessel and establish a lumen ${ }^{34,35}$ (Figure 2B). Depending on the location and organism, lumen formation can occur via different mechanisms including cord hollowing, vacuolar fusion or inverse membrane blebbing ${ }^{36,37}$. Lumenized sprouts eventually anastomose with neighbouring sprouts to generate new vascular loops, either via sprout hollowing (generating a multicellular tube) or by membrane invagination 
(resulting in a unicellular tube) ${ }^{38}$. The resulting blood flow stabilizes new connections, while non-perfused segments regress ${ }^{39}$. Through iterative cycles of this sprouting behaviour, ECs progressively expand the primary vascular plexus. Pre-existing vasculature can also expand by vessel splitting - a process termed intussusception ${ }^{40}$. However, the cellular mechanisms of intussusception are poorly defined.

\section{Tissue-specific mechanisms of vessel formation}

As development proceeds, new vascular beds form to support the growth and function of various organs (Figure 2A,B). Some vascular beds arise from a combination of vasculogenesis and angiogenesis, while others are formed exclusively by angiogenesis. Examples of the latter are the brain and retina. In these organs, angiogenic sprouting generates a plexus intermediate that subsequently remodels into a network of arteries, veins, and capillaries. Depending on the tissue characteristics, the cellular mechanisms of angiogenesis can differ. In the rigid bone tissue, ECs do not form motile sprouts but organize into columnar structures with multicellular buds that fuse to form vessel arches ${ }^{41}$. The cellular dynamics of ECs are also important for artery formation. In the retina, for instance, vein-derived tip cells continuously migrate from low-flow (veins) to high-flow (arteries) $\operatorname{areas}^{42}$ (Figure 3). Arteriovenous plasticity is also observed in other vascular beds that form via sprouting. For example, the arterial and venous components of the gastrointestinal vasculature in zebrafish have a common venous origin as it arises from a pool of specialized angioblasts residing in the floor of the posterior cardinal vein (PCV) ${ }^{43}$ (Figure 3 ). Other late-forming vascular beds also emerge from various cellular sources. The coronary vasculature of the heart, for instance, is formed by ECs derived from the sinus venosus, proepicardium, and endocardium that populate complementary regions of the heart ${ }^{44}$. The contribution of the endocardium to the coronary vasculature is only minimal in the embryonic heart $^{45}$. However, a population of endocardium-derived ECs generated through lineage conversion during trabecular compaction forms a substantial proportion of postnatal coronary vessels $^{46}$. The formation of a vascular bed from various endothelial sources is an effective mechanism to ensure adequate vascularization of essential organs such as the heart. Interestingly, heart ECs are also a source of MCs as endocardial ECs can convert into progenitors of PCs and vSMCs via endothelial-to-mesenchymal transition $(\text { EndoMT })^{47}$.

While it is thought that most ECs have the ability to proliferate and contribute to the growth of vascular beds, clonal expansion of ECs has also been reported (Figure 3). During inflammationinduced growth of the LN vasculature, ECs of HEVs represent local progenitors that undergo clonal proliferation to generate new $\mathrm{LN}$ capillaries and $\mathrm{HEVs}^{48}$. Studies in adult mice also 
suggested the existence of circulatory and vessel wall-resident progenitor cells that can be activated to promote vessel growth upon demand ${ }^{49}$ (Figure 3). However, their overall contribution to vascular growth remains debatable.

\section{Development of the lymphatic vasculature}

Lymphatic development begins only after functional blood circulation is established. The first lymphatic ECs (LECs) are generated through transdifferentiation of blood ECs (BECs). This process is instigated by the transcription factor PROX1 and occurs in certain veins such as the CV. Vascular endothelial growth factor C (VEGFC), binding to its receptor VEGFR3, stimulates the emigration of LECs out of veins ${ }^{50}$. After exiting the veins as streams of cells, LECs assemble in the jugular region of the embryo into the first primitive vessels, the primordial thoracic ducts and the peripheral longitudinal lymphatic vessels ${ }^{51,52}$ (Figure 2C). Venous sprouting also takes place in a few other locations in the embryo and generates four additional primitive lymphatic structures called lymph sacs, which expand further by lymphangiogenic sprouting (Figure 2C). In zebrafish, the ventral wall of the cardinal vein was shown to harbour specialized angioblasts that are a source of LECs ${ }^{53}$. Another study identified bi-potential PROX1-expressing precursors in the dorsal side of the vein that give rise to LECs through differential daughter-cell fate determination following VEGFC-induced division ${ }^{54}$. Whether ventral and dorsal precursors represent independent pools of LEC progenitors, and whether they are also present in mammalian veins is unknown.

In addition to the venous source of LECs, alternative cellular origins have been described in the chick $^{55}$, as well as in the murine mesentery, skin and heart ${ }^{56-59}$. The exact cellular origins are unclear except for the mesenteric vasculature that was shown to form through vasculogenic differentiation and assembly (lymphvasculogenesis) of cKit lineage cells derived from bloodforming hemogenic endothelium ${ }^{59}$ (Figure 2D). The contribution of macrophages to lymphatic vasculature has also been suggested, but could not be confirmed by lineage tracing studies ${ }^{58,60}$.

Together, these findings suggest that heterogeneity in endothelial origin may contribute to tissuespecific formation and specialization of vessels. However, further studies are needed to refine our understanding of the different EC origins, their organ-specific contributions as well as their functional significance.

\section{Regulation of vascular patterning}


Newly formed vascular beds must possess signalling mechanisms to adapt blood and lymphatic patterning to tissue architecture and demand. Below, both general and tissue-specific mechanisms of vessel density regulation are discussed.

\section{Vessel sprouting and branching}

A key trigger to form new vessel branches is tissue hypoxia, which leads to the secretion of proangiogenic growth factors and cytokines. The most extensively studied among these is VEGF, which binds to VEGF receptors (VEGFRs) on ECs to promote migration, proliferation and tip cell formation ${ }^{61}$. ECs with high VEGFR2/3 activation become tip cells and upregulate the Notch ligand DLL4 ${ }^{62}$. DLL4 induces stalk cell behaviour in adjacent ECs by activating NOTCH1 signalling, resulting in decreased expression of VEGFR2/3 and increased expression of VEGFR1 - a VEGF trap. Tip/stalk cell specification thus relies on differential VEGFR expression and relative VEGF sensitivities, which are established through DLL4/NOTCH1 ${ }^{62,63}$. During sprouting, the levels of VEGFRs are constantly changing as ECs face different environments, meet new cellular neighbours or undergo asymmetric cell division ${ }^{64-66}$. As a result, stalk cells can become tip cells and vice versa, allowing dynamic position changes in the growing vessel ${ }^{64}$. The dynamics of this tip/stalk cell shuffling also led to the model that ECs acquire a tip-cell phenotype when DLL4/NOTCH1 is inactive. However, more recent reports suggest that the stalk-cell phenotype needs to be actively suppressed to allow tip-cell formation. This suppression is mediated by NRP1, a co-receptor for VEGF and semaphorins, which establishes differential responsiveness to TGFß/BMP signalling ${ }^{67}$. Consistent with these data, BMP9 and BMP10 support stalk cell specification by activating Notch downstream target genes and their inhibition causes endothelial hypersprouting ${ }^{68-70}$.

As discussed above, another member of the VEGF family, VEGFC, is the key regulator of lymphatic vessel sprouting. It binds to the VEGF receptor VEGFR2, as well as to VEGFR3 that is mainly expressed in LECs. VEGFC activity is regulated by CCBE1-controlled and ADAMTS3-mediated proteolytic cleavage, which ensures that lymphangiogenesis is spatially and temporally controlled ${ }^{71-73}$. Analogous to the requirement of NRP1 as a co-receptor for VEGFR2 during VEGF-induced blood vessel sprouting ${ }^{61}$, NRP2 is essential for VEGFC/VEGFR3 induced lymphatic sprouting ${ }^{74}$. Several other known regulators of lymphatic sprouting also exert their effect by influencing VEGFC/VEGFR3 signalling. For instance, TGFßmediated activation of TGFBR2 and ALK 5 promotes LEC sprouting by regulating VEGFR3 and NRP2 expression ${ }^{75}$. Much less is known about the cellular mechanisms of lymphatic vessel 
formation. Existing evidence suggests that, at least in certain vascular beds, a similar tip/stalk cell-dependent process is at play ${ }^{76}$.

ECs utilize guidance molecules such as Slits, Netrins and Ephrins binding to Roundabout, UNC5 and $\mathrm{EphB}$ receptors, respectively, to navigate nascent vessels ${ }^{77}$. In some organs, vessels have been shown to co-pattern with nerves, with vessel-derived signals promoting extensions of nerves and vice versa ${ }^{78}$. Reciprocal guidance mechanisms also exist between different types of vessels, as shown during the formation of zebrafish trunk and murine mesenteric lymphatic vessels, where artery-derived CXCL12 regulates the migration of CXCR4 $4^{+} \mathrm{LECs}^{57,79}$. Notably, vessel growth is also regulated in a vascular bed-specific manner. Growth factors such as VEGFB promote vascular expansion in select tissues such as the heart and adipose tissue ${ }^{17,80}$. Another example is the sprouting from the axial vein in zebrafish which requires BMP but not VEGF signalling ${ }^{81}$. Also, canonical developmental pathways can have vascular bed-specific roles. This is exemplified in the blood vasculature of the bone as well as in the lacteals of the intestinal villi, where Notch does not restrict, rather promotes (lymph)angiogenic sprouting ${ }^{82,83}$.

Apart from hardwired signal transduction cascades, mechanical forces imposed by blood flow provide another layer of regulation. In vitro and in vivo studies showed that both luminal and transmural flow regulate angiogenic sprouting ${ }^{84-86}$. Also, endothelial metabolism is emerging as a major determinant of tip and stalk behaviour in the blood vasculature. This notion rests on the realization that angiogenic sprouting is metabolically demanding ${ }^{87}$. BECs primarily rely on glycolysis and increase flux through this pathway when activated by pro-angiogenic signals ${ }^{88}$. Enhanced glycolysis provides a competitive advantage for BECs to become a tip cell as glycolysis-derived ATP drives EC rearrangement and directional migration ${ }^{88}$. Conversely, reducing glycolysis compromises vascular expansion, as shown by blockade of the glycolytic activator PFKFB3 ${ }^{88}$. ECs also require fatty acid $\beta$-oxidation (FAO) for vessel sprouting. FAOderived carbons are used for nucleotide synthesis, which is required for DNA replication during EC proliferation ${ }^{89}$. Emerging evidence suggests that LECs also rely on FAO during lymph vessel growth $^{90}$.

\section{Vessel regression}

Vessel density regulation involves not only the formation of new vessel connections but also the removal of unnecessary ones (regression). EC apoptosis underlies the programmed regression of the transient hyaloid vasculature and pupillary membrane in the eye ${ }^{91}$, but does not account for physiological regression in other vascular beds ${ }^{92}$. Instead, dynamic rearrangements of ECs have been proposed as the central mechanism of regression leading to retraction of ECs from non- 
perfused vessel segments ${ }^{93-96}$. Lymphatic vasculature is believed to undergo similar remodelling events, as illustrated by the process by which mesenteric collecting vessels form from a plexus intermediate ${ }^{97,98}$. However, it is interesting to note that while airway inflammation-driven changes in blood vessel remodelling subside after resolution of the inflammatory response, hyperplasia of lymphatic vessels persists ${ }^{99,100}$. This suggests different mechanisms of vessel remodelling in blood and lymphatic vessels, at least during pathological conditions.

A key determining factor of regression is flow-induced shear stress ${ }^{93-95}$, which has also been implicated in the functional specialization of both blood and lymphatic vessels ${ }^{32,69,101,102}$. The influence of flow-dependent mechanical forces on vessel specialization is further discussed below.

\section{Vessel quiescence}

After having established new vascular networks, ECs resume quiescence. Quiescence is a reversible, non-dividing and non-migrating state common to most ECs in adult blood and lymphatic vessels, yet relatively little is known about its regulation. The importance of this regulation is however highlighted in vascular pathologies caused by aberrant activation of PI3K/AKT and RAS/MAPK signalling, the major mitogenic signalling cascades. Activating mutations in PIK3CA, encoding for the p110 $\alpha$ catalytic subunit of PI3K, drive venous and lymphatic malformations ${ }^{103-107}$, while inactivation of RASA1, a negative regulator of RAS, causes capillary malformation-arteriovenous malformation ${ }^{108}$ and lymphatic vessel hyperplasia $^{109}$. RAS signalling appears to be a pivotal antagonist of LEC quiescence ${ }^{110,111}$, which couples growth factor signalling to the PI3K pathway ${ }^{112}$.

The phosphatase PTEN, a negative regulator of PI3K/AKT signalling, and the transcription factor FOXO1, which is inactivated by AKT-mediated phosphorylation, are critical drivers of quiescence in BECs ${ }^{113,114}$. PTEN is induced by DLL4/NOTCH1 and arrests cell cycle progression in stalk cells ${ }^{113}$, while FOXO1 slows the proliferative and metabolic activity in $\mathrm{ECs}^{114}$. FOXO1-induced quiescence relies on the suppression of c-MYC, itself a potent activator of endothelial proliferation, growth, and metabolism ${ }^{114}$. A similar regulation of the metabolic and cell cycle machinery is caused by physiological laminar shear stress, a well-known instigator of EC quiescence. The effects of shear stress are transmitted by the transcription factor KLF2, which suppresses glycolytic (e.g. PFKFB3) and angiogenic (e.g. VEGFR2) genes, among others $^{115}$. Other quiescence-promoting factors in BECs are the BMP9/10, signalling through ALK1 and endoglin, and the cerebral cavernous malformation proteins (CCM1-3), whose inactivation causes hyperplastic vascular malformations ${ }^{68,69,116,117}$. Unlike BECs, LECs promote 
quiescence in response to oscillatory shear, mimicking disturbed flow, through an FOXC2dependent mechanism ${ }^{118}$. Inactivation of the transcription factor FOXC2 causes a loss of quiescence, which involves junction disassembly and a TAZ-dependent re-entry into the cell cycle $^{118}$.

Notably, ECs in certain tissues maintain a proliferative state or appear more susceptible to reinduction of growth after they have reached quiescence. For instance, LECs in lacteals continuously proliferate, presumably to cope with the permanently renewing environment of the small intestine ${ }^{83}$. In addition, activation of mTORC1 or inhibition of DLL4/NOTCH1 in adult mice causes loss of quiescence and vascular neoplasms in skin and liver, while other organs seem less affected ${ }^{119-121}$. Whether this tissue preference is a consequence of a particular tissue environment, vessel structure, or endothelial identity is unknown.

\section{Vessel specialization}

Vascular specialization involves not only differentiation into arteries, veins and lymphatic vessels but also into tissue-specific endothelia. Specialized ECs reciprocally shape their tissue environment by providing angiocrine signals that support organ function ${ }^{122,123}$ (Box 1). Endothelial specialization can be instructed by cell-intrinsic mechanisms, which exhibit organrestricted expression or activity, or by external tissue-derived signals, which act locally and are dependent on the microenvironment. A few of many such mechanisms are discussed below.

\section{Biochemical signals}

Biochemical signals play a key role in the first developmental event of EC specialization, the differentiation into arteries and veins. Notochord-derived sonic hedgehog induces VEGF, which subsequently evokes arterial specification of angioblasts that receive highest VEGF signalling ${ }^{31,32}$. Peripheral sensory nerves are another source of VEGF required for arterial differentiation in the skin blood vasculature ${ }^{124}$. Arterial specification by VEGF depends on the activation of ERK signalling downstream of its receptors VEGFR2 and NRP1 ${ }^{124}$. Sympathetic innervation can also promote arterial specification ${ }^{125}$. Sympathetic nerve terminals produce norepinephrine that activates the ERK pathway through binding to endothelial $\alpha 1$ and $\alpha 2$ adrenergic receptors ${ }^{125}$. Interestingly, ERK activation is also important for the specification of LEC fate downstream of VEGFC/VEGFR3 signalling ${ }^{73,126,127}$.

Compared to our understanding of arterio-venous fate specification, much less is known about signals and pathways that regulate functional specialization of vessels. Examples include ECM- 
derived cues, signalling through $\beta 1$ integrins, which control EC subtype specification in the developing bone ${ }^{128}$. Additional examples are the requirement of continuous VEGF signalling for the maintenance of fenestrated endothelium in adult tissues ${ }^{129}$ as well as the role of the angiopoietin (ANG)/TIE2 system in adopting a postcapillary venule phenotype that enables leukocyte adhesion during inflammation ${ }^{130}$. The formation of lymphatic valves is perhaps one of the best-described mechanisms of functional specialization and involves several pathways including FOXC2/Calcineurin/NFATc1, EphrinB2/EphB4, Connexin, Integrin-alpha9/FN-EIIIA and ANG/TIE signalling ${ }^{9,131}$. Signalling by ANG2/TIE2 is also critical for the formation of button-like junctions in lymphatic capillaries ${ }^{132}$.

\section{Transcriptional programmes}

Transcriptional mechanisms are essential for not only endothelial lineage specification, but also for determining vessel- and organ-specific EC identities. A prime example is the acquisition of arterial-venous differentiation, which is co-determined by a network of transcriptional regulators. Among these are the FOXC and SOXF families of transcription factors, which drive arterial differentiation, in part, by enhancing endothelial Notch signalling ${ }^{133,134}$. SOX17, for instance, is enriched in the arterial endothelium of mice and its deletion results in a failure to form $\operatorname{arteries}^{135}$. Venous identity, on the other hand, is regulated by NR2F2, a transcriptional regulator expressed in venous, but not arterial $\mathrm{ECs}^{32}$. Consistent with the centrality of Notch in determining arterial identity, NR2F2 promotes venous differentiation by suppressing Notch signalling. NR2F2 is also involved in lymphatic differentiation. In venous LEC progenitors, NR2F2 and SOX18 transactivate the master regulator of LEC fate, PROX1 ${ }^{136,137}$, which subsequently drives its own expression by interacting with NR2F2 ${ }^{138,139}$. In complex with PROX1, NR2F2 is unable to suppress Notch target genes and instead supports LEC-specific gene expression ${ }^{138}$.

While these transcription factors are crucial in specifying general EC identity of vessel types, others endow ECs with organ-specific attributes. Examples are MEOX2 and TCF15, which program heart ECs to efficiently transfer FAs to the myocardium ${ }^{15}$. Consistent with such tissuerestricted transcriptional activities, genetic manipulation of certain transcription factors leads to organ-specific vascular phenotypes. An example is that of FOXOs, whose inactivation causes organ-restricted hemangiomas that correlate with organ-specific gene expression changes ${ }^{140}$. Moreover, ECs of each organ have been shown to express unique sets of transcription factors ${ }^{141}$, suggesting that combinatorial responses restrict endothelial phenotypes to specific tissue compartments. However, the transcriptional patterns that establish tissue-specific endothelial 
differentiation are yet to be determined.

\section{Mechanical forces}

ECs face different types of mechanical forces generated by the elasticity of the extracellular matrix (ECM), the pulling forces of their neighbours, as well as flow-driven shear stress, luminal pressure, cyclic circumferential stretch and cellular transmigration ${ }^{9,142}$ (Figure 4). ECs sense and transmit external forces through their cell-cell and cell-ECM adhesions that also generate intrinsic traction forces. Endothelial glycocalyx and primary cilia have additionally been implicated in EC force sensing ${ }^{143,144}$. Signalling pathways that convert mechanical information into biological responses, so-called mechanotransduction, and the effects of different force types on BECs and LECs have been reviewed elsewhere ${ }^{9,142,145}$. Here we focus on the shear stressdriven processes that are specifically implicated in vessel remodelling and specialization.

Studies in chick embryos have demonstrated the pivotal role of blood flow in driving remodelling of the primitive yolk sac vasculature and specialization of arteries ${ }^{32,146}$. Shear stress controls the expression of EC lineage-specific genes in a dosage-dependent manner. For example, ECs exposed to high shear stress show increased expression of the arterial genes EphrinB2, NRP1 and Connexin $40^{32,146}$. On the contrary, PROX1 that defines the identity of the low-flow lymphatic vessels is downregulated under high shear ${ }^{147}$.

As discussed above, physiological laminar flow has a stabilizing effect and promotes EC quiescence, while long-term exposure to high or low shear induces vessel remodelling to adjust lumen diameter. Both blood and lymphatic ECs respond to physiological laminar shear by reorganizing their actin cytoskeleton and focal adhesions and aligning in the direction of flow. However, under high shear stress ECs align perpendicular to the flow direction ${ }^{148}$. While progress has been made in understanding general flow-sensing mechanisms ${ }^{142,145}$, much less is known about how ECs interpret shear stress magnitude and what determines the differential flow responses in endothelial subtypes. It has been proposed that arterial, venous and lymphatic ECs exhibit different shear stress sensitivities, so called set points that determine the range of shear stress within which to respond ${ }^{9,142}$. This set point was shown to be determined by levels of VEGFR3 ${ }^{148}$, a component of the PECAM1/VE-cadherin/VEGFR mechanosensory complex, which is highly expressed in low-flow lymphatic vessels but low in blood endothelia.

Different regions of the vascular tree face not only different magnitudes but also different patterns of flow ranging from pulsatile flow in arteries to lower constant flow in veins, and complex flow patterns in venous and lymphatic valves. The pattern of flow regulates endothelial 
gene expression and cellular responses. For instance, disturbed flow at vessel branch points provides a signal for the initiation of valve morphogenesis via upregulation of the transcription factors FOXC2 and GATA2 ${ }^{118,149,150}$. Distinct flow patterns in different regions of mature valves may further explain region-specific molecular and morphological differences and determine the unique identity of valve ECs. This is highlighted by the shared expression of genes previously thought to be restricted to lymphatic and/or arterial endothelium such as PROX1, FOXC2, Integrin- $\alpha 9$ and Ephrin-B2 in both venous and lymphatic valves ${ }^{18,151,152}$. Besides intraluminal shear stresses, lymphatic vessels and lymphatic capillaries, in particular, are exposed to transmural flow, which was shown to promote permeability and cell-cell junction reorganization ${ }^{153}$. Transmural flow may thus contribute to the specialization of button-like junctions in lymphatic capillaries.

Flow also regulates various aspects of vessel morphogenesis and function in disease states. Disturbed blood flow in vessel branch points, bifurcations and curvatures promotes BEC proliferation and inflammatory activation and predisposes these sites for atherosclerosis ${ }^{142,154}$. Furthermore, the aetiology of certain vascular malformations is linked to abnormal flow regulation, which will be further discussed below.

\section{Metabolism}

ECs are exposed to various environments differing in oxygen tension, nutrient abundance, and metabolite accumulation. For instance, ECs at the blood-air barrier in the lung face high oxygen levels, whereas ECs in the bone marrow cavity or in lymphatic vessels are confronted with relatively hypoxic conditions. The influence of such metabolic environments on endothelial specialization has not been studied in detail yet. However, given the ability of ECs to sense and respond to metabolic cues ${ }^{87}$, it seems likely that tissue metabolism provides a range of signals that contribute to EC heterogeneity. For instance, the differentiation of mesodermal progenitors into angioblasts is stimulated by low levels of oxygen and involves signalling by hypoxiainducible factors (HIFs) ${ }^{155}$. Oxygen abundance also impacts EC metabolism with consequences for endothelial bioenergetics and function. A shortage of oxygen impedes enzymatic reactions that require oxygen (e.g. FAO) and disrupts redox balance ${ }^{156}$. Apart from oxygen, altered nutrient availability can redirect metabolic fluxes and thereby lead to the accumulation of metabolites that affect signalling and gene expression. An example is acetyl coenzyme A (acetylCoA), a central metabolite of energy metabolism, whose acetyl group is required for the posttranslational modification of proteins ${ }^{156}$. Studies in LECs have shown that FAO-derived acetyl-CoA contributes to lymphatic gene expression as it used by the acetyltransferase p300 to 
acetylate histones at PROX1 target genes ${ }^{90}$. Other studies have demonstrated that non-histone proteins such as VEGFR2 and NOTCH1 are also regulated by acetylation ${ }^{157,158}$, which suggest that endothelial function is modulated in tune with their metabolic resources.

Tissue metabolites can also act as paracrine signalling molecules. 3-hydroxybutyrate (3-HIB) is an intermediate of BCAA metabolism produced in skeletal muscle, which stimulates FA transport across the endothelium to fuel lipid catabolism in myofibers ${ }^{159}$. Another example is lactate, the end product of glycolysis. ECs take up lactate from the extracellular milieu via the monocarboxylate transporter MCT1, which activates HIF signalling ${ }^{160}$. ECs exposed to lactate also increase the expression of VEGF and other receptor tyrosine ligands, overall promoting their angiogenic behaviour ${ }^{161}$.

\section{Vessel type- and vascular bed-specific diseases}

Vascular heterogeneity is apparent in many diseases ${ }^{2}$. For instance, inflammatory blood vessel diseases often affect specific vessels or vascular beds and systemic diseases such as diabetes or hyperlipidemia show predilection sites for atherosclerotic lesion development. Certain tumours preferentially metastasize through particular vascular beds, and signals from the tumour microenvironment determine tumour vessel heterogeneity that influences responsiveness to therapy ${ }^{162}$. Perhaps the clearest examples for vessel type- or organ-restricted disease manifestation are vascular malformations. These diseases commonly arise from abnormalities in ECs and are categorized according to the vessel type that is perturbed (Table 2). Sequencing efforts have identified causative mutations for each type of malformation (Table 2). For instance, activating mutations in TIE2 or its downstream effector PIK3CA cause the majority of venous malformations (VMs), which constitute the most common vascular malformations ${ }^{103,106-108}$. Somatic activating mutations in PIK3CA also account for the majority of lymphatic malformations (LMs) ${ }^{104,105}$. Mutations in TIE2 have not been found in LMs, but in another organ-type-specific vascular disease affecting the Schlemm's canal - a 'lymphatic-like' vessel collecting aqueous humor from the eye $\mathrm{e}^{101,163,164}$. TIE2 haploinsufficiency causes Schlemm's canal hypoplasia that provokes primary congenital glaucoma in humans ${ }^{165}$.

Apart from affecting specific vessel types, vascular malformations can manifest in an organspecific manner. Cerebral cavernous malformations (CCMs), for instance, are vascular malformations of venous origin that primarily affect the central nervous system (CNS) ${ }^{117}$. The enlarged and rupture-prone lesions arise from loss-of-function mutations in one of the three CCM genes (CCM1-3). These proteins function in a complex that controls junctional 
organisation and polarity. Increased RhoA activation in CCM lesions has been found to contribute to junctional disintegration ${ }^{166}$, while defective flow responses, aberrant angiogenesis as well as TGFß/BMP-induced EndoMT were shown to promote lesion formation ${ }^{167-169}$. Further studies have shown that loss of CCM proteins results in increased activity of MEKK3 and its flow-responsive targets KLF2 and KLF4 ${ }^{169-171}$. The proangiogenic versus vasoprotective roles of KLF2 in low-flow versus high-flow vessels, respectively, were proposed as a potential explanation as to why veins are more prone to form CCM lesions ${ }^{169}$. However, the reasons for the CNS-restricted occurrence of CCMs are not clear. Factors from the neurovascular microenvironment may be important. Since lesion formation requires on-going angiogenesis ${ }^{168,172}$, it is possible that the brain vasculature, due to its late development, is particularly sensitive to CCM formation. Cerebral ischemia-induced angiogenesis could additionally explain aging-associated increase in lesion number ${ }^{172}$. Interestingly, angiogenic stimuli are also required for the induction of arteriovenous malformations (AVMs) in mice lacking the TGF $\beta$ type I receptor, ALK1, that model human hereditary hemorrhagic telangiectasia $(\mathrm{HHT})^{173}$. The rupture-prone AVMs in HHT form from direct connections between arteries and veins and are found in the brain as well as in the lung, liver and gastrointestinal tract. Defective BMP/ALK1/ENG-dependent, flow-induced inhibition of EC proliferation and mural cell recruitment was suggested to underlie AVM formation in mice ${ }^{116}$. Imaging of the initial flow-dependent stages of AVM formation in zebrafish ${ }^{174,175}$ instead revealed impaired migration of ALK1-deficient cells against the flow, leading to an increase in distal arterial calibre and EC number ${ }^{176}$. Overall, these studies suggest that disruption of endothelial flow response mechanisms contributes to the formation of different types of vascular malformations.

In addition to LMs, genetic diseases of the lymphatic system include hereditary lymphedema whose clinical forms are classified depending on the underlying mutation and affected body part $^{177}$. To date, more than 20 causative genes have been identified, many of them centring on VEGFR3 signalling and the resultant reduction in pathway activity ${ }^{178}$. Interestingly, some of these mutations primarily affect either collecting vessels or lymphatic capillaries. For example, Milroy disease, caused by inactivating mutations in VEGFR3, is characterized by hypoplasia and/or dysfunction of lymphatic capillaries ${ }^{131}$. Notably, VEGFR3 is present in all LECs and the question as to what determines vessel-type specific disease manifestation remains unclear.

\section{Conclusion and perspective}


Heterogeneity within the endothelium is increasingly recognized in both normal and disease conditions, affecting vascular architecture, structure, and function. The diversity of phenotypes ECs can adopt suggests substantial plasticity and indicates that heterogeneity is a core endothelial property that allows ECs to fulfil their multiple tasks. Tissue- and cell type-specific genetic models are starting to give insights into the mechanisms that govern organ- and vessel type-specific endothelial differentiation and point to the complexity of the mechanisms involved. However, our understanding of endothelial heterogeneity is in its infancy, and numerous fundamental questions remain. For instance, what are the origins and sources of organ-specific ECs and how do they influence vessel specialization? Is endothelial specialization bounded by cell-autonomous mechanisms or is it imposed by the microenvironment? If so, what are the key signals and pathways and how are they regulated? While the role of growth factor signalling cascades and transcription factors is the best-understood aspect of tissue-specific endothelial differentiation at present, it seems likely that the role of mechanical forces and metabolism will gain increasing attention. Although these signals are not EC-specific, they may establish a particular environment or cellular state permissive for endothelial differentiation. In this context, it will be of particular interest to investigate the link between tissue environment, endothelial epigenetic state, and phenotype, given recent studies that highlight the influence of metabolism on epigenetics and cellular differentiation ${ }^{156}$. Such studies will also have to take into account which source of ECs is used for the analysis. Until now, most in vitro studies in the vascular field are based on a limited number of EC model systems (e.g. HUVECs, HDLECs), ignoring tissue-specific differences in phenotype and, function. Addressing these questions and challenges promises to reveal exciting new perspectives on mechanisms of vascular development and function, with implications for a variety of vascular diseases. 


\section{Acknowledgement}

There is much outstanding work in the field that could not be cited in this review due to the space constraints and we ask the forbearance of our colleagues. We thank Max Fiedler for assistance with the artwork. M.P. is supported by the Max Planck Society, the European Research Council (ERC) Starting Grant ANGIOMET (311546), the Deutsche Forschungsgemeinschaft (SFB 834), the Excellence Cluster Cardiopulmonary System (EXC 147/1), the LOEWE grant Ub-Net, the DZHK (German Center for Cardiovascular Research), the Stiftung Charité, and the European Molecular Biology Organization Young Investigator Programme. The work of T.M. is funded by the Swedish Research Council, the Swedish Cancer Foundation, the European Research Council (ERC-2014-CoG-646849) and Knut and Alice Wallenbergs Foundation. 


\section{Figures}

Figure 1 | Organisation of the vasculature. | The vasculature is organised into hierarchical networks of arteries (red), veins (blue) and interconnected capillaries, as well as blind-ended lymphatic capillaries and collecting vessels (green) that drain fluid into the venous circulation. Arterioles, capillaries, and venules constitute the microvasculature, the site where most of the intercellular communication occurs. Large arteries and veins are characterised by continuous lining of ECs, BM and layers of SMCs. Blood capillary ECs can be continuous, fenestrated or discontinuous, and they have a varying extent of BM and pericyte coverage. Lymphatic capillaries consist of oak-leaf shaped ECs with specialised button-like junctions and anchoring filaments that pull ECs apart and allow entry of fluid under conditions of high interstitial pressure. Collecting lymphatic vessels have a sparse SMC coverage and luminal valves that help the pumping and prevent backflow of lymph, respectively. Anatomy of capillary vessels is shown at the top and larger vessels at the bottom of the figure. Pink, EC; yellow; basement membrane (BM); purple, smooth muscle (SMC); grey, pericyte; orange, tunica adventitia (outer connective tissue covering of the vessel).

Figure 2 | Processes of vascular development. a | Endothelial progenitor cells, angioblasts, differentiate from mesoderm, acquire arterial or venous fate and assemble into the first embryonic blood vessels, the cardinal vein and the dorsal aorta. In the extraembryonic yolk sac, angioblasts first assemble into blood islands that fuse to form a primary vessel network. b | Expansion of the network is achieved through angiogenesis that generates new vessels and vascular circuits from pre-existing ones through vessel sprouting, branching and anastamosis. CNS, central nervous system. c| The first lymphatic endothelial cells transdifferentiate from venous EC in the cardinal vein between E9.5-9.75 and migrate out of the veins to form the first primitive lymphatic structures, primordial thoracic duct (pTD) and peripheral longitudinal lymphatic vessel (PLLV) (top). Further expansion of the vasculature occurs through lymphangiogenic sprouting that generates a primary vascular plexus (bottom). d | Certain lymphatic vascular beds such as the mesentery form through lymphvasculogenic assembly of vessels from non-venous derived progenitors. (Lymph)vasculogenesis is restricted to embryonic development, while (lymph)angiogenesis also occurs during postnatal development. Examples of tissues vascularised by the above described processes are indicated. 
Figure 3 | Origins and sources of ECs during vascular development. Mesodermally derived angioblasts form the first major vessels, the dorsal aorta and the cardinal vein. Expansion of the vasculature occurs through proliferation of pre-existing ECs. Clonal expansion of local progenitors within high endothelial venules has been reported in the adult lymph node. Incorporation of circulating or vessel wall resident endothelial progenitor cells may also contribute to neovascularisation in the adult. Vein-derived tip cells migrate against the blood flow and contribute to the formation of arteries. Specialized angioblasts on the floor of the cardinal vein form both the organ-specific gastrointestinal vasculature as well as LECs in zebrafish embryos. In mammals, the first LECs are generated through transdifferentiation of venous ECs in the cardinal vein and the intersomitic veins. Non-venous derived LEC progenitors of hemogenic endothelial origin, or yet an unknown origin, additionally contribute to the lymphatic vasculature of certain organs.

Figure 4 | Mechanical forces in the blood and lymph vasculature. ECs are confronted with different types of mechanical forces generated by tissue elasticity, pulling forces of neighbouring cells, as well as flow-driven shear stress, luminal pressure, cyclic circumferential stretch and cellular transmigration. The magnitude and patterns of these forces differ depending on the organ or vessel ECs reside in. Arteries form a high-pressure system, which enables the directed transportation of blood to the capillary bed, whereas veins and lymphatics face low-pressure gradients and have valves to prevent back flow. Also, organ function generates mechanical forces. Muscle contractions in skeletal muscle or the heart exert strain on the vessel wall. ECs sense and transmit different types of external forces primarily through their cell-cell and cellECM adhesions that also generate intrinsic traction forces. Different types of forces exerted on ECs of different vessel types are shown by arrows as indicated. 


\section{Boxes}

\section{Box 1 | Vascular instructive functions}

ECs are specialized by signals from the tissue environment but vice versa also influence the tissue they invade. Independent of their tissue-nourishing function, ECs secrete growth factors, chemokines, and extracellular matrix components, or present signalling molecules on their cell surface, which act on cells in their vicinity. These so-called 'angiocrine factors' signal in a paracrine fashion and instruct organ morphogenesis, homeostasis and regeneration ${ }^{122,123}$. In the developing embryo, for instance, the formation and patterning of the heart, pancreas, liver, lung, and kidney are regulated by EC-derived signals leading to morphogenesis defects when ECs are missing $^{123}$. Organ homeostasis in adult mice is also instructed by angiocrine signals. Studies in liver have shown that renewal of hepatocytes is guided by WNT signals that are deployed by ECs in the central vein of the liver lobule ${ }^{179}$. By producing WNT2 and WNT9b, these ECs maintain adjacent AXIN2-expressing precursor cells that renew the liver under homeostatic conditions. A different pattern of angiocrine signals mediates liver regeneration in response to injury. Liver sinusoidal ECs (LSECs) release WNT2, hepatocyte growth factor (HGF), and angiopoietin 2 (ANG2), which together support reconstitution of liver mass and function ${ }^{180,181}$. Interestingly, ANG2 coordinates hepatocyte and EC proliferation, thereby ensuring adequate vascular supply of the newly forming parenchyma ${ }^{181}$. However, unbalanced angiocrine signalling can also drive pathology, as shown in chronic liver injury where prevalent signalling by the SDF1 receptor CXCR4 causes fibrosis ${ }^{182}$.

Endothelial-derived signals also establish niches for stem and progenitor cells including hematopoietic stem cells, neural stem cells, and spermatogonial stem cells ${ }^{122}$. A prime example is bone, in which specialized ECs help to sustain osteoprogenitor cells, the precursors of boneforming cells, and hematopoietic stem cells (HSCs), which establish the hematopoietic system $^{122,123}$. Osteoprogenitor cells associate with so-called type $\mathrm{H}$ endothelium found at the distal end of the bone arterial network. Type H ECs are characterized by high expression of the endothelial markers CD31 and Endomucin and release essential osteogenic signals (e.g. FGFs, PDGFs, BMPs), thereby promoting osteogenesis ${ }^{3}$. Notably, age-induced bone loss can be reversed by boosting type $\mathrm{H}$ vessel formation through HIF and Notch ${ }^{3,82}$ suggesting that type $\mathrm{H}$ vessel-derived angiocrine signalling is essential for maintaining bone function. Endothelial Notch signalling also promotes the expansion of HSC niches in the bone and involves type $\mathrm{H}$ ECs, the formation of arterioles / arteries and the expansion of perivascular cells ${ }^{183}$. Together, 
these data highlight the gatekeeper function of the endothelium, and demonstrate that endothelial manipulation is sufficient to alter tissue differentiation, homeostasis and regeneration. 


\section{References}

1 Aspelund, A., Robciuc, M. R., Karaman, S., Makinen, T. \& Alitalo, K. Lymphatic System in Cardiovascular Medicine. Circ Res 118, 515-530, d (2016).

2 Aird, W. C. Endothelial cell heterogeneity. Cold Spring Harb Perspect Med 2, a006429, (2012).

3 Kusumbe, A. P., Ramasamy, S. K. \& Adams, R. H. Coupling of angiogenesis and osteogenesis by a specific vessel subtype in bone. Nature 507, 323-328, (2014).

4 Di Russo, J. et al. Vascular laminins in physiology and pathology. Matrix Biol, (2016).

5 Armulik, A. et al. Pericytes regulate the blood-brain barrier. Nature 468, 557-561, (2010).

6 Armulik, A., Genove, G. \& Betsholtz, C. Pericytes: developmental, physiological, and pathological perspectives, problems, and promises. Dev Cell 21, 193-215, (2011).

7 Hall, C. N. et al. Capillary pericytes regulate cerebral blood flow in health and disease. Nature 508, 55-60, (2014).

8 Hill, R. A. et al. Regional Blood Flow in the Normal and Ischemic Brain Is Controlled by Arteriolar Smooth Muscle Cell Contractility and Not by Capillary Pericytes. Neuron 87, 95-110, (2015).

9 Sabine, A., Saygili Demir, C. \& Petrova, T. V. Endothelial Cell Responses to Biomechanical Forces in Lymphatic Vessels. Antioxid Redox Signal 25, 451-465, (2016).

10 Zhao, Z., Nelson, A. R., Betsholtz, C. \& Zlokovic, B. V. Establishment and Dysfunction of the Blood-Brain Barrier. Cell 163, 1064-1078, (2015).

11 Ben-Zvi, A. et al. Mfsd2a is critical for the formation and function of the blood-brain barrier. Nature 509, 507-511, (2014).

12 Nguyen, L. N. et al. Mfsd2a is a transporter for the essential omega-3 fatty acid docosahexaenoic acid. Nature 509, 503-506, (2014).

13 Itkin, T. et al. Distinct bone marrow blood vessels differentially regulate haematopoiesis. Nature 532, 323-328, (2016).

14 Baluk, P. et al. Functionally specialized junctions between endothelial cells of lymphatic vessels. J Exp Med 204, 2349-2362, (2007).

15 Coppiello, G. et al. Meox2/Tcf15 heterodimers program the heart capillary endothelium for cardiac fatty acid uptake. Circulation 131, 815-826, (2015).

16 Hagberg, C. E. et al. Vascular endothelial growth factor B controls endothelial fatty acid uptake. Nature 464, 917-921, (2010).

17 Kivela, R. et al. VEGF-B-induced vascular growth leads to metabolic reprogramming and ischemia resistance in the heart. EMBO molecular medicine 6, 307-321, (2014).

18 Dijkstra, M. H. et al. Lack of cardiac and high-fat diet induced metabolic phenotypes in two independent strains of Vegf-b knockout mice. Scientific reports 4, 6238, (2014).

19 Winkler, E. A. et al. GLUT1 reductions exacerbate Alzheimer's disease vasculo-neuronal dysfunction and degeneration. Nat Neurosci 18, 521-530, (2015).

20 Jais, A. et al. Myeloid-Cell-Derived VEGF Maintains Brain Glucose Uptake and Limits Cognitive Impairment in Obesity. Cell 165, 882-895, (2016).

21 Tarlungeanu, D. C. et al. Impaired Amino Acid Transport at the Blood Brain Barrier Is a Cause of Autism Spectrum Disorder. Cell 167, 1481-1494.e1418, (2016).

22 Lee, M. et al. Transcriptional programs of lymphoid tissue capillary and high endothelium reveal control mechanisms for lymphocyte homing. Nat Immunol 15, 982995, (2014). 
23 Girard, J. P., Moussion, C. \& Forster, R. HEVs, lymphatics and homeostatic immune cell trafficking in lymph nodes. Nat Rev Immunol 12, 762-773, (2012).

24 Planas-Paz, L. et al. Mechanoinduction of lymph vessel expansion. EMBO J 31, 788-804, (2012).

25 Reischauer, S. et al. Cloche is a bHLH-PAS transcription factor that drives haematovascular specification. Nature 535, 294-298, (2016).

26 Paffett-Lugassy, N. et al. Heart field origin of great vessel precursors relies on nkx2.5mediated vasculogenesis. Nature cell biology 15, 1362-1369, (2013).

27 Proulx, K., Lu, A. \& Sumanas, S. Cranial vasculature in zebrafish forms by angioblast cluster-derived angiogenesis. Dev Biol 348, 34-46, (2010).

28 Siekmann, A. F., Standley, C., Fogarty, K. E., Wolfe, S. A. \& Lawson, N. D. Chemokine signaling guides regional patterning of the first embryonic artery. Genes Dev 23, 22722277, (2009).

29 Herbert, S. P. et al. Arterial-venous segregation by selective cell sprouting: an alternative mode of blood vessel formation. Science 326, 294-298, (2009).

30 Lindskog, H. et al. Molecular identification of venous progenitors in the dorsal aorta reveals an aortic origin for the cardinal vein in mammals. Development 141, 1120-1128, (2014).

31 Kohli, V., Schumacher, J. A., Desai, S. P., Rehn, K. \& Sumanas, S. Arterial and venous progenitors of the major axial vessels originate at distinct locations. Dev Cell 25, 196206, (2013).

32 Marcelo, K. L., Goldie, L. C. \& Hirschi, K. K. Regulation of endothelial cell differentiation and specification. Circ Res 112, 1272-1287, (2013).

33 Helker, C. S. et al. The hormonal peptide Elabela guides angioblasts to the midline during vasculogenesis. Elife 4, (2015).

34 Potente, M., Gerhardt, H. \& Carmeliet, P. Basic and therapeutic aspects of angiogenesis. Cell 146, 873-887, (2011).

35 Betz, C., Lenard, A., Belting, H. G. \& Affolter, M. Cell behaviors and dynamics during angiogenesis. Development 143, 2249-2260, (2016).

36 Charpentier, M. S. \& Conlon, F. L. Cellular and molecular mechanisms underlying blood vessel lumen formation. Bioessays 36, 251-259, (2014).

37 Gebala, V., Collins, R., Geudens, I., Phng, L. K. \& Gerhardt, H. Blood flow drives lumen formation by inverse membrane blebbing during angiogenesis in vivo. Nature cell biology 18, 443-450, (2016).

38 Herwig, L. et al. Distinct cellular mechanisms of blood vessel fusion in the zebrafish embryo. Curr Biol 21, 1942-1948, (2011).

39 Korn, C. \& Augustin, H. G. Mechanisms of Vessel Pruning and Regression. Dev Cell 34, 5-17, (2015).

40 Gianni-Barrera, R., Trani, M., Reginato, S. \& Banfi, A. To sprout or to split? VEGF, Notch and vascular morphogenesis. Biochem Soc Trans 39, 1644-1648, (2011).

41 Ramasamy, S. K. et al. Blood flow controls bone vascular function and osteogenesis. Nat Commun 7, 13601, (2016).

$42 \mathrm{Xu}, \mathrm{C}$. et al. Arteries are formed by vein-derived endothelial tip cells. Nat Commun 5, 5758, (2014).

43 Hen, G. et al. Venous-derived angioblasts generate organ-specific vessels during zebrafish embryonic development. Development 142, 4266-4278, (2015). 
44 Chen, H. I. et al. The sinus venosus contributes to coronary vasculature through VEGFCstimulated angiogenesis. Development 141, 4500-4512, (2014).

45 Zhang, H. et al. Endocardium Minimally Contributes to Coronary Endothelium in the Embryonic Ventricular Free Walls. Circ Res 118, 1880-1893, (2016).

46 Tian, X. et al. Vessel formation. De novo formation of a distinct coronary vascular population in neonatal heart. Science 345, 90-94, (2014).

47 Chen, Q. et al. Endothelial cells are progenitors of cardiac pericytes and vascular smooth muscle cells. Nat Commun 7, 12422, (2016).

48 Mondor, I. et al. Clonal Proliferation and Stochastic Pruning Orchestrate Lymph Node Vasculature Remodeling. Immunity 45, 877-888, (2016).

49 Basile, D. P. \& Yoder, M. C. Circulating and tissue resident endothelial progenitor cells. J Cell Physiol 229, 10-16, (2014).

50 Karkkainen, M. J. et al. Vascular endothelial growth factor C is required for sprouting of the first lymphatic vessels from embryonic veins. Nat Immunol 5, 74-80, (2004).

51 Yang, Y. et al. Lymphatic endothelial progenitors bud from the cardinal vein and intersomitic vessels in mammalian embryos. Blood 120, 2340-2348, (2012).

52 Hagerling, R. et al. A novel multistep mechanism for initial lymphangiogenesis in mouse embryos based on ultramicroscopy. Embo j 32, 629-644, (2013).

53 Nicenboim, J. et al. Lymphatic vessels arise from specialized angioblasts within a venous niche. Nature 522, 56-61, (2015).

54 Koltowska, K. et al. Vegfc Regulates Bipotential Precursor Division and Prox1 Expression to Promote Lymphatic Identity in Zebrafish. Cell Rep 13, 1828-1841, (2015).

55 Wilting, J. et al. Dual origin of avian lymphatics. Dev Biol 292, 165-173, (2006).

56 Klotz, L. et al. Cardiac lymphatics are heterogeneous in origin and respond to injury. Nature 522, 62-67, (2015).

57 Mahadevan, A. et al. The left-right Pitx2 pathway drives organ-specific arterial and lymphatic development in the intestine. Dev Cell 31, 690-706, (2014).

58 Martinez-Corral, I. et al. Nonvenous origin of dermal lymphatic vasculature. Circ Res 116, 1649-1654, (2015).

59 Stanczuk, L. et al. cKit Lineage Hemogenic Endothelium-Derived Cells Contribute to Mesenteric Lymphatic Vessels. Cell Rep, (2015).

60 Gordon, E. J. et al. Macrophages define dermal lymphatic vessel calibre during development by regulating lymphatic endothelial cell proliferation. Development 137, 3899-3910, (2010).

61 Simons, M., Gordon, E. \& Claesson-Welsh, L. Mechanisms and regulation of endothelial VEGF receptor signalling. Nat Rev Mol Cell Biol 17, 611-625, (2016).

62 Blanco, R. \& Gerhardt, H. VEGF and Notch in tip and stalk cell selection. Cold Spring Harb Perspect Med 3, a006569, (2013).

63 Zarkada, G., Heinolainen, K., Makinen, T., Kubota, Y. \& Alitalo, K. VEGFR3 does not sustain retinal angiogenesis without VEGFR2. Proc Natl Acad Sci U S A 112, 761-766, (2015).

64 Jakobsson, L. et al. Endothelial cells dynamically compete for the tip cell position during angiogenic sprouting. Nature cell biology 12, 943-953, (2010).

65 Nakayama, M. et al. Spatial regulation of VEGF receptor endocytosis in angiogenesis. Nature cell biology 15, 249-260, (2013). 
66 Costa, G. et al. Asymmetric division coordinates collective cell migration in angiogenesis. Nature cell biology, (2016).

67 Aspalter, I. M. et al. Alk1 and Alk5 inhibition by Nrp1 controls vascular sprouting downstream of Notch. Nat Commun 6, 7264, (2015).

68 Larrivee, B. et al. ALK1 signaling inhibits angiogenesis by cooperating with the Notch pathway. Dev Cell 22, 489-500, (2012).

69 Ricard, N. et al. BMP9 and BMP10 are critical for postnatal retinal vascular remodeling. Blood 119, 6162-6171, (2012).

70 Moya, I. M. et al. Stalk cell phenotype depends on integration of Notch and Smad1/5 signaling cascades. Dev Cell 22, 501-514, (2012).

71 Jeltsch, M. et al. CCBE1 enhances lymphangiogenesis via A disintegrin and metalloprotease with thrombospondin motifs-3-mediated vascular endothelial growth factor-C activation. Circulation 129, 1962-1971, (2014).

72 Bui, H. M. et al. Proteolytic activation defines distinct lymphangiogenic mechanisms for VEGFC and VEGFD. J Clin Invest 126, 2167-2180, (2016).

73 Le Guen, L. et al. Ccbe1 regulates Vegfc-mediated induction of Vegfr3 signaling during embryonic lymphangiogenesis. Development 141, 1239-1249, (2014).

$74 \mathrm{Xu}, \mathrm{Y}$. et al. Neuropilin-2 mediates VEGF-C-induced lymphatic sprouting together with VEGFR3. J Cell Biol 188, 115-130, (2010).

75 James, J. M., Nalbandian, A. \& Mukouyama, Y. S. TGFbeta signaling is required for sprouting lymphangiogenesis during lymphatic network development in the skin. Development 140, 3903-3914, (2013).

76 Zheng, W. et al. Notch restricts lymphatic vessel sprouting induced by vascular endothelial growth factor. Blood 118, 1154-1162, (2011).

77 Adams, R. H. \& Eichmann, A. Axon guidance molecules in vascular patterning. Cold Spring Harb Perspect Biol 2, a001875, (2010).

78 Jones, C. A. \& Li, D. Y. Common cues regulate neural and vascular patterning. Curr Opin Genet Dev 17, 332-336, (2007).

79 Cha, Y. R. et al. Chemokine signaling directs trunk lymphatic network formation along the preexisting blood vasculature. Dev Cell 22, 824-836, (2012).

80 Robciuc, M. R. et al. VEGFB/VEGFR1-Induced Expansion of Adipose Vasculature Counteracts Obesity and Related Metabolic Complications. Cell metabolism 23, 712-724, (2016).

81 Wiley, D. M. et al. Distinct signalling pathways regulate sprouting angiogenesis from the dorsal aorta and the axial vein. Nature cell biology 13, 686-692, (2011).

82 Ramasamy, S. K., Kusumbe, A. P., Wang, L. \& Adams, R. H. Endothelial Notch activity promotes angiogenesis and osteogenesis in bone. Nature 507, 376-380, (2014).

83 Bernier-Latmani, J. et al. DLL4 promotes continuous adult intestinal lacteal regeneration and dietary fat transport. J Clin Invest 125, 4572-4586, (2015).

84 Galie, P. A. et al. Fluid shear stress threshold regulates angiogenic sprouting. Proc Natl Acad Sci U S A 111, 7968-7973, (2014).

85 Ghaffari, S., Leask, R. L. \& Jones, E. A. Flow dynamics control the location of sprouting and direct elongation during developmental angiogenesis. Development 142, 4151-4157, (2015).

86 Song, J. W. \& Munn, L. L. Fluid forces control endothelial sprouting. Proc Natl Acad Sci US A 108, 15342-15347, (2011). 
87 Potente, M. \& Carmeliet, P. M. The Link Between Angiogenesis and Endothelial Metabolism. Annual Review of Physiology 79, null, (2017).

88 De Bock, K. et al. Role of PFKFB3-driven glycolysis in vessel sprouting. Cell 154, 651663, (2013).

89 Schoors, S. et al. Fatty acid carbon is essential for dNTP synthesis in endothelial cells. Nature 520, 192-197, (2015).

90 Wong, B. W. et al. The role of fatty acid beta-oxidation in lymphangiogenesis. Nature 542, 49-54, (2017).

91 Lobov, I. B. et al. WNT7b mediates macrophage-induced programmed cell death in patterning of the vasculature. Nature 437, 417-421, (2005).

92 Watson, E. C. et al. Apoptosis regulates endothelial cell number and capillary vessel diameter but not vessel regression during retinal angiogenesis. Development 143, 29732982, (2016).

93 Chen, Q. et al. Haemodynamics-driven developmental pruning of brain vasculature in zebrafish. PLoS Biol 10, e1001374, (2012).

94 Franco, C. A. et al. Dynamic endothelial cell rearrangements drive developmental vessel regression. PLoS Biol 13, e1002125, (2015).

95 Kochhan, E. et al. Blood flow changes coincide with cellular rearrangements during blood vessel pruning in zebrafish embryos. PLoS One 8, e 75060, (2013).

96 Lenard, A. et al. Endothelial cell self-fusion during vascular pruning. PLoS Biol 13, e1002126, (2015).

97 Bazigou, E. et al. Integrin-alpha9 is required for fibronectin matrix assembly during lymphatic valve morphogenesis. Dev Cell 17, 175-186, (2009).

98 Norrmen, C. et al. FOXC2 controls formation and maturation of lymphatic collecting vessels through cooperation with NFATc1. J Cell Biol 185, 439-457, (2009).

99 Baluk, P. et al. Pathogenesis of persistent lymphatic vessel hyperplasia in chronic airway inflammation. J Clin Invest 115, 247-257, (2005).

100 Yao, L. C., Baluk, P., Feng, J. \& McDonald, D. M. Steroid-resistant lymphatic remodeling in chronically inflamed mouse airways. Am J Pathol 176, 1525-1541, (2010).

101 Park, D. Y. et al. Lymphatic regulator PROX1 determines Schlemm's canal integrity and identity. J Clin Invest 124, 3960-3974, (2014).

102 Sweet, D. T. et al. Lymph flow regulates collecting lymphatic vessel maturation in vivo. J Clin Invest 125, 2995-3007, (2015).

103 Limaye, N. et al. Somatic Activating PIK3CA Mutations Cause Venous Malformation. Am J Hum Genet 97, 914-921, (2015).

104 Luks, V. L. et al. Lymphatic and other vascular malformative/overgrowth disorders are caused by somatic mutations in PIK3CA. J Pediatr 166, 1048-1054 e1041-1045, (2015).

105 Osborn, A. J. et al. Activating PIK3CA alleles and lymphangiogenic phenotype of lymphatic endothelial cells isolated from lymphatic malformations. Hum Mol Genet 24, 926-938, (2015).

106 Castillo, S. D. et al. Somatic activating mutations in Pik3ca cause sporadic venous malformations in mice and humans. Sci Transl Med 8, 332ra343, d (2016).

107 Castel, P. et al. Somatic PIK3CA mutations as a driver of sporadic venous malformations. Sci Transl Med 8, 332ra342, (2016).

108 Uebelhoer, M., Boon, L. M. \& Vikkula, M. Vascular anomalies: from genetics toward models for therapeutic trials. Cold Spring Harb Perspect Med 2, (2012). 
109 Lapinski, P. E. et al. RASA1 maintains the lymphatic vasculature in a quiescent functional state in mice. $J$ Clin Invest 122, 733-747, (2012).

110 Ichise, T., Yoshida, N. \& Ichise, H. H-, N- and Kras cooperatively regulate lymphatic vessel growth by modulating VEGFR3 expression in lymphatic endothelial cells in mice. Development 137, 1003-1013, (2010).

111 Roth Flach, R. J. et al. Endothelial Mitogen-Activated Protein Kinase Kinase Kinase Kinase 4 Is Critical for Lymphatic Vascular Development and Function. Mol Cell Biol 36, 1740-1749, (2016).

112 Gupta, S. et al. Binding of ras to phosphoinositide 3-kinase p110alpha is required for rasdriven tumorigenesis in mice. Cell 129, 957-968, (2007).

113 Serra, H. et al. PTEN mediates Notch-dependent stalk cell arrest in angiogenesis. Nat Commun 6, 7935, (2015).

114 Wilhelm, K. et al. FOXO1 couples metabolic activity and growth state in the vascular endothelium. Nature 529, 216-220, (2016).

115 Doddaballapur, A. et al. Laminar shear stress inhibits endothelial cell metabolism via KLF2-mediated repression of PFKFB3. Arteriosclerosis, thrombosis, and vascular biology 35, 137-145, (2015).

116 Baeyens, N. et al. Defective fluid shear stress mechanotransduction mediates hereditary hemorrhagic telangiectasia. J Cell Biol 214, 807-816, (2016).

117 Fischer, A., Zalvide, J., Faurobert, E., Albiges-Rizo, C. \& Tournier-Lasserve, E. Cerebral cavernous malformations: from CCM genes to endothelial cell homeostasis. Trends $\mathrm{Mol}$ Med 19, 302-308, (2013).

118 Sabine, A. et al. FOXC2 and fluid shear stress stabilize postnatal lymphatic vasculature. $J$ Clin Invest 125, 3861-3877, (2015).

119 Sun, S. et al. Constitutive Activation of mTORC1 in Endothelial Cells Leads to the Development and Progression of Lymphangiosarcoma through VEGF Autocrine Signaling. Cancer Cell 28, 758-772, (2015).

120 Yan, M. et al. Chronic DLL4 blockade induces vascular neoplasms. Nature 463, E6-7, (2010).

121 Liu, Z. et al. Notch1 loss of heterozygosity causes vascular tumors and lethal hemorrhage in mice. J Clin Invest 121, 800-808, (2011).

122 Rafii, S., Butler, J. M. \& Ding, B. S. Angiocrine functions of organ-specific endothelial cells. Nature 529, 316-325, (2016).

123 Ramasamy, S. K., Kusumbe, A. P. \& Adams, R. H. Regulation of tissue morphogenesis by endothelial cell-derived signals. Trends Cell Biol 25, 148-157, (2015).

124 Simons, M. \& Eichmann, A. Molecular controls of arterial morphogenesis. Circ Res 116, 1712-1724, (2015).

125 Pardanaud, L. et al. Sympathetic Innervation Promotes Arterial Fate by Enhancing Endothelial ERK Activity. Circ Res 119, 607-620, (2016).

126 Shin, M. et al. Vegfc acts through ERK to induce sprouting and differentiation of trunk lymphatic progenitors. Development, (2016).

127 Deng, Y., Atri, D., Eichmann, A. \& Simons, M. Endothelial ERK signaling controls lymphatic fate specification. J Clin Invest 123, 1202-1215, (2013).

128 Langen, U. H. et al. Cell-matrix signals specify bone endothelial cells during developmental osteogenesis. Nature cell biology, (2017).

129 Kamba, T. et al. VEGF-dependent plasticity of fenestrated capillaries in the normal adult microvasculature. Am J Physiol Heart Circ Physiol 290, H560-576, (2006). 
130 Fuxe, J. et al. Angiopoietin/Tie2 signaling transforms capillaries into venules primed for leukocyte trafficking in airway inflammation. Am J Pathol 176, 2009-2018, (2010).

131 Koltowska, K., Betterman, K. L., Harvey, N. L. \& Hogan, B. M. Getting out and about: the emergence and morphogenesis of the vertebrate lymphatic vasculature. Development 140, 1857-1870, (2013).

132 Zheng, W. et al. Angiopoietin 2 regulates the transformation and integrity of lymphatic endothelial cell junctions. Genes Dev 28, 1592-1603, (2014).

133 Corada, M., Morini, M. F. \& Dejana, E. Signaling pathways in the specification of arteries and veins. Arteriosclerosis, thrombosis, and vascular biology 34, 2372-2377, (2014).

134 Hermkens, D. M. et al. Sox7 controls arterial specification in conjunction with hey2 and efnb2 function. Development 142, 1695-1704, (2015).

135 Corada, M. et al. Sox17 is indispensable for acquisition and maintenance of arterial identity. Nat Commun 4, 2609, (2013).

136 Srinivasan, R. S. et al. The nuclear hormone receptor Coup-TFII is required for the initiation and early maintenance of Prox 1 expression in lymphatic endothelial cells. Genes Dev 24, 696-707, (2010).

137 Francois, M. et al. Sox18 induces development of the lymphatic vasculature in mice. Nature 456, 643-647, (2008).

138 Aranguren, X. L. et al. COUP-TFII orchestrates venous and lymphatic endothelial identity by homo- or hetero-dimerisation with PROX1. J Cell Sci 126, 1164-1175, (2013).

139 Lee, S. et al. Prox1 physically and functionally interacts with COUP-TFII to specify lymphatic endothelial cell fate. Blood 113, 1856-1859, (2009).

140 Paik, J. H. et al. FoxOs are lineage-restricted redundant tumor suppressors and regulate endothelial cell homeostasis. Cell 128, 309-323, (2007).

141 Nolan, D. J. et al. Molecular signatures of tissue-specific microvascular endothelial cell heterogeneity in organ maintenance and regeneration. Dev Cell 26, 204-219, (2013).

142 Baeyens, N., Bandyopadhyay, C., Coon, B. G., Yun, S. \& Schwartz, M. A. Endothelial fluid shear stress sensing in vascular health and disease. J Clin Invest 126, 821-828, (2016).

143 Tarbell, J. M., Simon, S. I. \& Curry, F. R. Mechanosensing at the vascular interface. Annu Rev Biomed Eng 16, 505-532, (2014).

144 Goetz, J. G. et al. Endothelial cilia mediate low flow sensing during zebrafish vascular development. Cell Rep 6, 799-808, (2014).

145 Kutys, M. L. \& Chen, C. S. Forces and mechanotransduction in 3D vascular biology. Curr Opin Cell Biol 42, 73-79, (2016).

146 Buschmann, I. et al. Pulsatile shear and Gja5 modulate arterial identity and remodeling events during flow-driven arteriogenesis. Development 137, 2187-2196, (2010).

147 Chen, C. Y. et al. Blood flow reprograms lymphatic vessels to blood vessels. J Clin Invest 122, 2006-2017, (2012).

148 Baeyens, N. et al. Vascular remodeling is governed by a VEGFR3-dependent fluid shear stress set point. Elife 4, (2015).

149 Sabine, A. et al. Mechanotransduction, PROX1, and FOXC2 cooperate to control connexin 37 and calcineurin during lymphatic-valve formation. Dev Cell 22, 430-445, (2012). 
150 Kazenwadel, J. et al. GATA2 is required for lymphatic vessel valve development and maintenance. $J$ Clin Invest 125, 2979-2994, (2015).

151 Munger, S. J. et al. Segregated Foxc2, NFATc1 and Connexin expression at normal developing venous valves, and Connexin-specific differences in the valve phenotypes of Cx37, Cx43, and Cx47 knockout mice. Dev Biol 412, 173-190, (2016).

152 Bazigou, E. et al. Genes regulating lymphangiogenesis control venous valve formation and maintenance in mice. J Clin Invest 121, 2984-2992, (2011).

153 Miteva, D. O. et al. Transmural flow modulates cell and fluid transport functions of lymphatic endothelium. Circ Res 106, 920-931, (2010).

154 Morbiducci, U. et al. Atherosclerosis at arterial bifurcations: evidence for the role of haemodynamics and geometry. Thromb Haemost 115, 484-492, (2016).

155 Ramirez-Bergeron, D. L. et al. Hypoxia affects mesoderm and enhances hemangioblast specification during early development. Development 131, 4623-4634, (2004).

156 Pavlova, N. N. \& Thompson, C. B. The Emerging Hallmarks of Cancer Metabolism. Cell metabolism 23, 27-47, (2016).

157 Zecchin, A. et al. Reversible acetylation regulates vascular endothelial growth factor receptor-2 activity. J Mol Cell Biol 6, 116-127, (2014).

158 Guarani, V. et al. Acetylation-dependent regulation of endothelial Notch signalling by the SIRT1 deacetylase. Nature 473, 234-238, (2011).

159 Jang, C. et al. A branched-chain amino acid metabolite drives vascular fatty acid transport and causes insulin resistance. Nat Med 22, 421-426, (2016).

160 Vegran, F., Boidot, R., Michiels, C., Sonveaux, P. \& Feron, O. Lactate influx through the endothelial cell monocarboxylate transporter MCT1 supports an NF-kappaB/IL-8 pathway that drives tumor angiogenesis. Cancer Res 71, 2550-2560, (2011).

161 Ruan, G. X. \& Kazlauskas, A. Lactate engages receptor tyrosine kinases Axl, Tie2, and vascular endothelial growth factor receptor 2 to activate phosphoinositide 3-kinase/Akt and promote angiogenesis. J Biol Chem 288, 21161-21172, (2013).

162 Phoenix, T. N. et al. Medulloblastoma Genotype Dictates Blood Brain Barrier Phenotype. Cancer Cell 29, 508-522, (2016).

163 Aspelund, A. et al. The Schlemm's canal is a VEGF-C/VEGFR-3-responsive lymphaticlike vessel. J Clin Invest 124, 3975-3986, (2014).

164 Kizhatil, K., Ryan, M., Marchant, J. K., Henrich, S. \& John, S. W. Schlemm's canal is a unique vessel with a combination of blood vascular and lymphatic phenotypes that forms by a novel developmental process. PLoS Biol 12, e1001912, (2014).

165 Souma, T. et al. Angiopoietin receptor TEK mutations underlie primary congenital glaucoma with variable expressivity. J Clin Invest 126, 2575-2587, d (2016).

166 Stockton, R. A., Shenkar, R., Awad, I. A. \& Ginsberg, M. H. Cerebral cavernous malformations proteins inhibit Rho kinase to stabilize vascular integrity. $J$ Exp Med 207, 881-896, d (2010).

167 Maddaluno, L. et al. EndMT contributes to the onset and progression of cerebral cavernous malformations. Nature 498, 492-496, (2013).

168 Mleynek, T. M. et al. Lack of CCM1 induces hypersprouting and impairs response to flow. Hum Mol Genet 23, 6223-6234, (2014).

169 Renz, M. et al. Regulation of beta1 integrin-Klf2-mediated angiogenesis by CCM proteins. Dev Cell 32, 181-190, (2015).

170 Cuttano, R. et al. KLF4 is a key determinant in the development and progression of cerebral cavernous malformations. EMBO molecular medicine 8, 6-24, (2015). 
171 Zhou, Z. et al. Cerebral cavernous malformations arise from endothelial gain of MEKK3KLF2/4 signalling. Nature 532, 122-126, (2016).

172 Boulday, G. et al. Developmental timing of CCM2 loss influences cerebral cavernous malformations in mice. J Exp Med 208, 1835-1847, (2011).

173 Park, S. O. et al. Real-time imaging of de novo arteriovenous malformation in a mouse model of hereditary hemorrhagic telangiectasia. J Clin Invest 119, 3487-3496, (2009).

174 Corti, P. et al. Interaction between alk1 and blood flow in the development of arteriovenous malformations. Development 138, 1573-1582, (2011).

175 Laux, D. W. et al. Circulating Bmp10 acts through endothelial Alk1 to mediate flowdependent arterial quiescence. Development 140, 3403-3412, (2013).

176 Rochon, E. R., Menon, P. G. \& Roman, B. L. Alk1 controls arterial endothelial cell migration in lumenized vessels. Development 143, 2593-2602, (2016).

177 Connell, F. C. et al. The classification and diagnostic algorithm for primary lymphatic dysplasia: an update from 2010 to include molecular findings. Clin Genet 84, 303-314, (2013).

178 Brouillard, P., Boon, L. \& Vikkula, M. Genetics of lymphatic anomalies. J Clin Invest 124, 898-904, (2014).

179 Wang, B., Zhao, L., Fish, M., Logan, C. Y. \& Nusse, R. Self-renewing diploid Axin2(+) cells fuel homeostatic renewal of the liver. Nature 524, 180-185, (2015).

180 Ding, B. S. et al. Inductive angiocrine signals from sinusoidal endothelium are required for liver regeneration. Nature 468, 310-315, (2010).

$181 \mathrm{Hu}, \mathrm{J}$. et al. Endothelial cell-derived angiopoietin-2 controls liver regeneration as a spatiotemporal rheostat. Science 343, 416-419, (2014).

182 Ding, B. S. et al. Divergent angiocrine signals from vascular niche balance liver regeneration and fibrosis. Nature 505, 97-102, (2014).

183 Kusumbe, A. P. et al. Age-dependent modulation of vascular niches for haematopoietic stem cells. Nature 532, 380-384, (2016). 


\section{Highlighted references}

1 Kusumbe, A. P., Ramasamy, S. K. \& Adams, R. H. Coupling of angiogenesis and osteogenesis by a specific vessel subtype in bone. Nature 507, 323-328, (2014).

These studies characterize two distinct capillary subtypes in the bone vaculature, which play key roles in maintaining cells of the bone- and blood-forming system.

2 Armulik, A. et al. Pericytes regulate the blood-brain barrier. Nature 468, 557-561, (2010).

In this study, the critical regulatory role of pericytes at the blood-brain barrier is demonstrated.

3 Tărlungeanu, Dora C. et al. Impaired Amino Acid Transport at the Blood Brain Barrier Is a Cause of Autism Spectrum Disorder. Cell 167, 1481-1494.e1418.

This study demonstrates a critical function of endothelial Slc7a5 in transporting branched-chain amino acids across the blood brain barrier and thereby maintaining normal brain function.

4 Planas-Paz, L. et al. Mechanoinduction of lymph vessel expansion. EMBO J 31, 788-804, (2012).

This study implicates interstitial fluid pressure induced cell streching in the activation of the VEGFR3 growth factor receptor and induction of lymphatic vascular expansion.

5 Reischauer, S. et al. Cloche is a bHLH-PAS transcription factor that drives haematovascular specification. Nature 535, 294-298, (2016).

This study identifies the transcription factor NPAS4L as the gene that is mutated in the avascular cloche mutant in zebrafish.

6 Gebala, V., Collins, R., Geudens, I., Phng, L. K. \& Gerhardt, H. Blood flow drives lumen formation by inverse membrane blebbing during angiogenesis in vivo. Nature cell biology 18, 443-450, (2016).

This study identifies a novel mechanism of lumen formation in the angiogenic sprout, which involves pressure-driven inverse membrane blebbing of ECs.

$7 \mathrm{Xu}, \mathrm{C}$. et al. Arteries are formed by vein-derived endothelial tip cells. Nat Commun 5, 5758, (2014).

This paper shows that venous tip cells contribute to the formation of arteries by migrating against the direction of flow.

8 Mondor, I. et al. Clonal Proliferation and Stochastic Pruning Orchestrate Lymph Node Vasculature Remodeling. Immunity 45, 877-888, (2016).

This study identifies local progenitor cells within high endothelial venules that proliferate clonally during inflammation induced expansion of the lymph node vasculature.

9 Koltowska, K. et al. Vegfc Regulates Bipotential Precursor Division and Prox1 Expression to Promote Lymphatic Identity in Zebrafish. Cell Rep 13, 1828-1841, (2015).

This study demonstrates that LEC differentiation is achieved through differential daughter cell fate determination following venous progenitor cell division in zebrafish. 
10 Stanczuk, L. et al. cKit Lineage Hemogenic Endothelium-Derived Cells Contribute to Mesenteric Lymphatic Vessels. Cell Rep, (2015).

This study identifies cKit lineage cells of hemogenic endothelial origin as a new organ-specific source of mesenteric lymphatic vessels.

11 Costa, G. et al. Asymmetric division coordinates collective cell migration in angiogenesis. Nature cell biology, (2016).

This study demonstrates that asymmetric cell division contributes to tip/stalk cell selection.

12 De Bock, K. et al. Role of PFKFB3-driven glycolysis in vessel sprouting. Cell 154, 651663, (2013).

In this study, the importance of metabolic regulation and PFKFB3-driven glycolysis for endothelial sprouting is revealed.

13 Wilhelm, K. et al. FOXO1 couples metabolic activity and growth state in the vascular endothelium. Nature 529, 216-220, (2016).

This paper identifies the forkhead transcription factor FOXO1 as a key driver of endothelial quiescence, which lowers EC metabolism through suppression of c-MYC signalling.

14 Sabine, A. et al. FOXC2 and fluid shear stress stabilize postnatal lymphatic vasculature. $J$ Clin Invest 125, 3861-3877, (2015).

This study shows how mechanical forces generated by recirculating flow in valve regions define identity, and how the mechano-sensitive transcription factor FOXC2 maintains quiescence and integrity of lymphatic endothelium.

15 Nolan, D. J. et al. Molecular signatures of tissue-specific microvascular endothelial cell heterogeneity in organ maintenance and regeneration. Dev Cell 26, 204-219, (2013).

This paper exemplifies the molecular heterogeneity within the endothelium showing that organ-specific ECs express unique combinations of transcription factors and signaling molecules. 
Web site of Michael Potente's laboratory: www.angio-met-lab.com

Web site of Taija Mäkinen's laboratory: makinenlab.com

\section{Glossary terms}

\section{Angioblast}

EC precursor cells that differentiate from the mesoderm and form the first embryonic blood vessels.

\section{Blood-brain barrier}

A selective permeability barrier that restricts the passage of solutes from the circulating blood to the brain.

\section{Basement membrane}

Sheet-like extracellular matrix structure that separates endothelium from the underlying tissue.

\section{Fatty acid $\beta$-oxidation (FAO)}

A catabolic process in mitochondria during which fatty acids are broken down to generate substrates for the TCA cycle and the electron transport chain.

\section{Fenestrated endothelium}

Endothelium that is permeated with pores (fenestrae)

\section{Glaucoma}

A group of eye diseases caused by damage to the optic nerve and resulting loss of vision.

\section{Glycocalyx (endothelial)}

Coating of the apical surface of ECs composed of proteoglycans and glycoproteins that plays a role in mechanotransduction, signalling, hemostasis and blood cell interactions. 


\section{Glycolysis}

An oxygen-independent metabolic pathway that converts glucose into pyruvate to generate energy and biomass precursors.

\section{Hemangioma}

Benign vascular tumour composed of an increased number of ECs.

\section{Hemogenic endothelium}

Specialised ECs present within certain embryonic blood vessels that can give rise to hematopoietic cells during a restricted window of development.

\section{Lumen formation}

The formation of the interior space of a vessel through which blood of lymph flows.

\section{Lymphedema}

Fluid accumulation and tissue swelling due to dysfunction of lymphatic vessels.

\section{Mesoderm}

The middle layer of the three germ layers in the early embryo that forms connective tissues, including endothelium, and muscle.

\section{Notochord}

A transient midline structure forming in chordate embryos that provides signals for the patterning of the surrounding tissues.

\section{Primary cilium}

A non-motile microtubule based antenna-like sensory organelle. 


\section{Progenitor cells}

Early descendants of stem cell that can divide a limited number of time and differentiated into a few cell types.

\section{Protein acetylation}

Protein acetylation is an important post-translational protein modification by which an acetylgroup is added to a lysine residue or to the $\mathrm{N}$-terminus of a protein.

\section{Stem cell niche}

A microenvironment that supports the undifferentiated and self-renewable state of stem cells.

\section{Transcytosis}

Transport of macromolecules across the cell.

\section{Transmural flow}

Fluid flow through the endothelial layer. 


\section{Online summary}

- Blood and lymphatic vessels are lined by a single layer of endothelial cells (ECs) whose molecular signatures and functional properties are dependent on the type of vessel and tissue they reside in.

- Depending on the developmental state, vascular bed or (patho-)physiological context, blood and lymphatic vessels can form via different mechanisms and from various cellular origins. Heterogeneity in endothelial origin may contribute to tissue-specific formation and specialization of vessels

- Vessel- and organ-specific specialisation is partly governed by cell-intrinsic developmental pathways and transcriptional programmes, which control processes such as EC differentiation, proliferation and growth.

- Tissue microenvironment plays an important role in co-determining blood and lymph vessel heterogeneity. Key elements of these environmental signals are mechanical forces, metabolism, cell-matrix and cell-cell interactions as well as organotypic growth factors that adapt vessel size, shape, and function to the needs of the underlying tissue.

- Vessels reciprocally instruct tissue differentiation and function by producing 'angiocrine' factors that act on cells in their vicinity.

- Diseases arising from primary abnormalities in EC including vascular malformations often affect a specific vessel type or vascular bed. What determines such organ- and vessel-type specific disease manifestations remains unclear. 


\section{Author biographies}

Michael Potente is a research group leader at the Max Planck Institute for Heart and Lung Research. He is a trained cardiologist, who combines basic science and clinical practice. Following his doctoral work with Rudi Busse, Michael Potente did his residency in Internal Medicine and Cardiology with Andreas Zeiher at the University of Frankfurt, Germany. In parallel to that, he performed postdoctoral training with Stefanie Dimmeler at the same institution. His work focuses on the regulation of angiogenesis by metabolism.

Taija Mäkinen is Associate Professor at Uppsala University. She carried out doctoral work with Kari Alitalo at the University of Helsinki, Finland. After postdoctoral studies with Rüdiger Klein at the Max Planck Institute of Neurobiology, Germany, she established her laboratory at the Cancer Research UK London Research Institute, before relocating to Uppsala. Her laboratory studies the molecules and mechanisms underlying lymphatic vascular development and disorders. 


\section{Figure 1}

Blood capillary

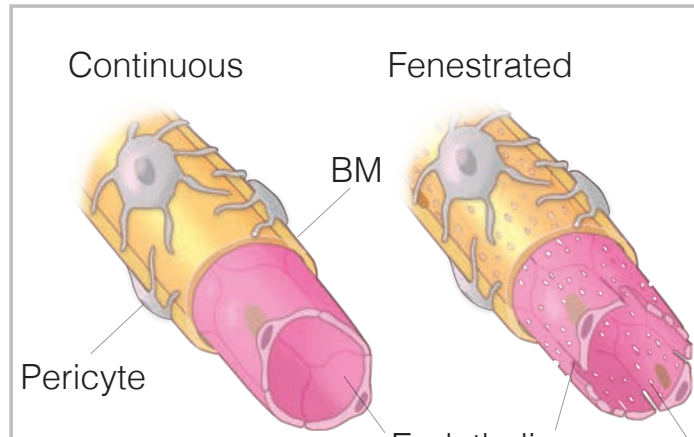

Endothelium

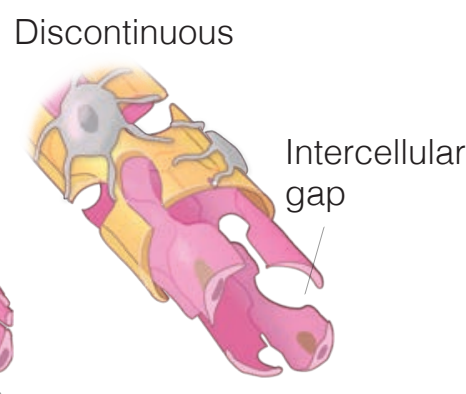

Fenestration
Lymphatic capillary

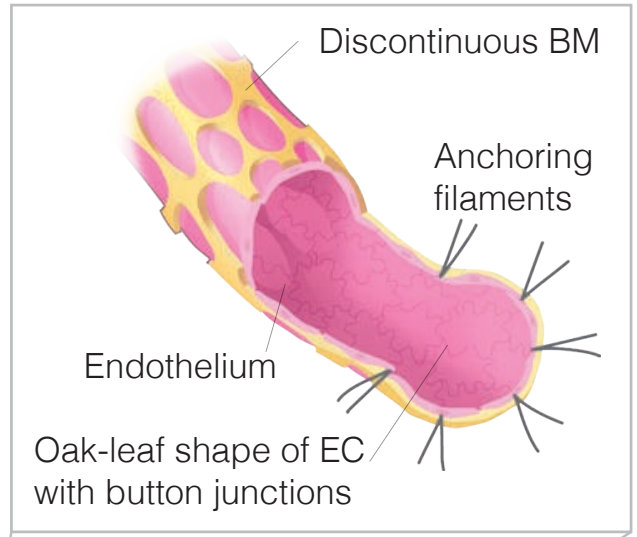

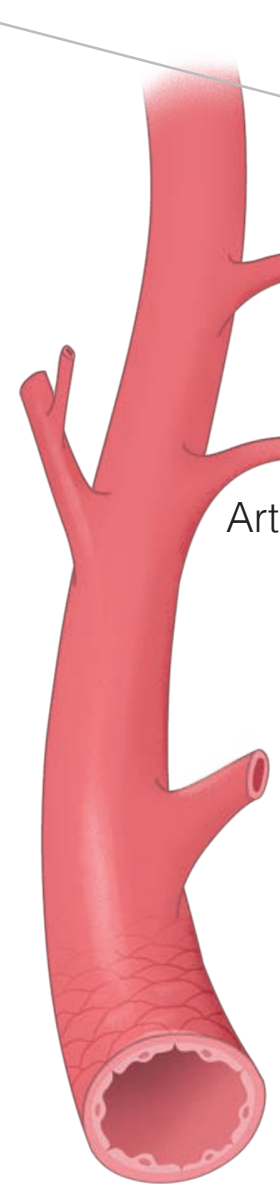

Artery

Capillary bed

Artery
Collecting lymphatic vessel

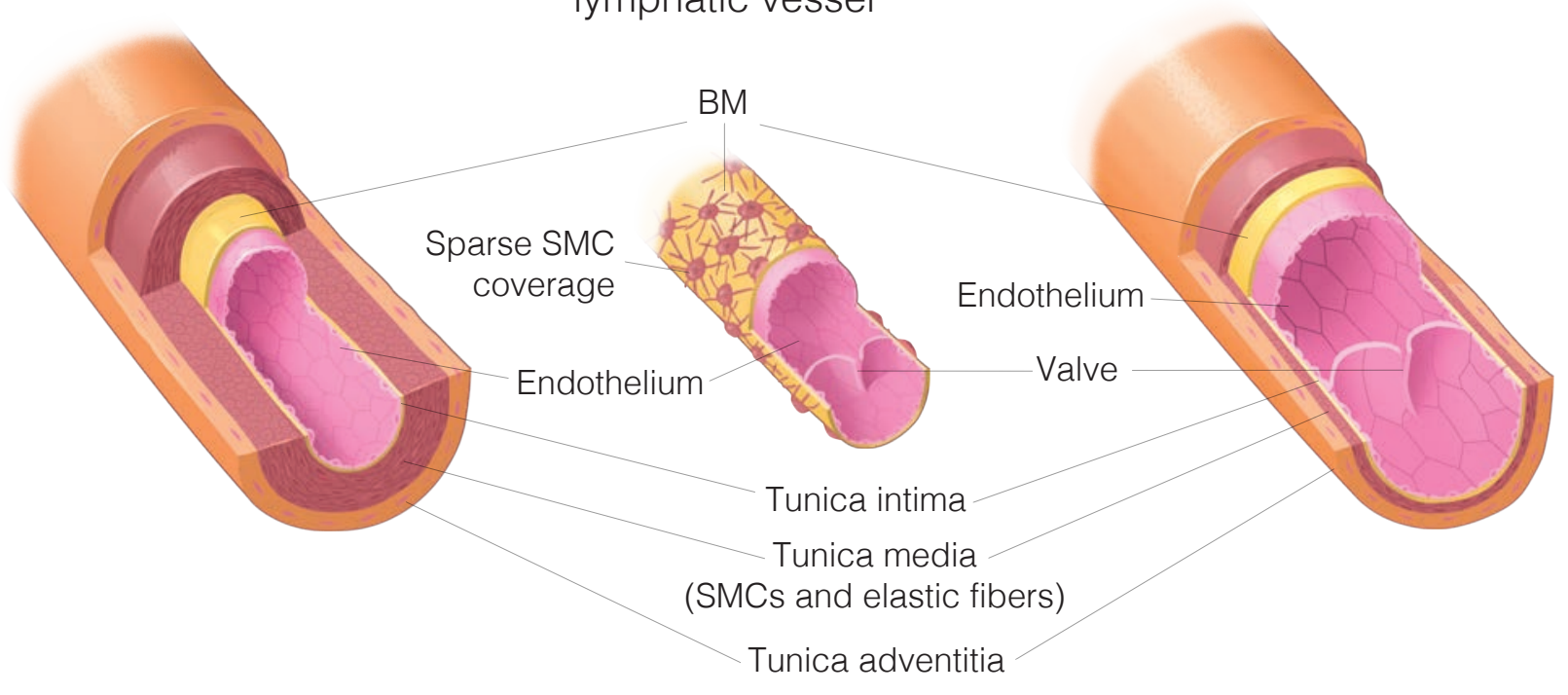

\section{lymphatic vessel}
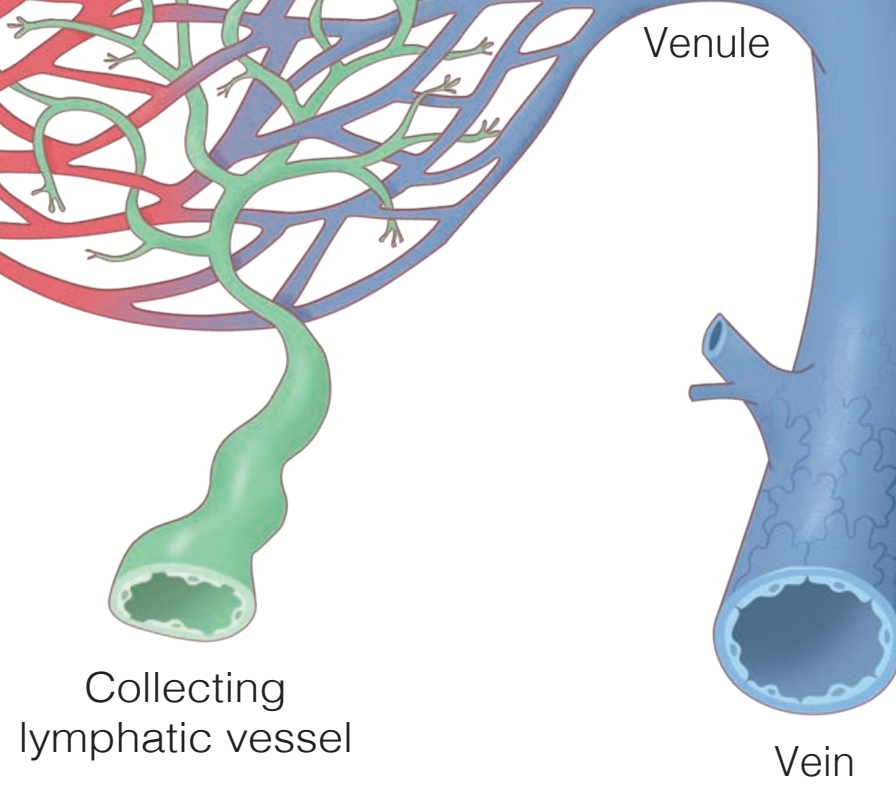

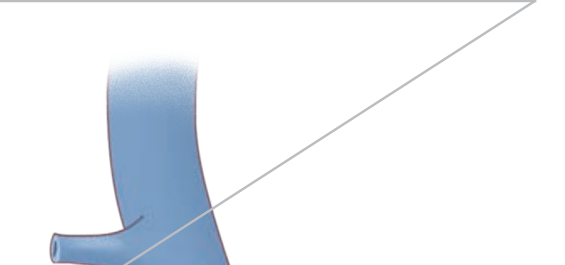


Figure 2

a Vasculogenesis

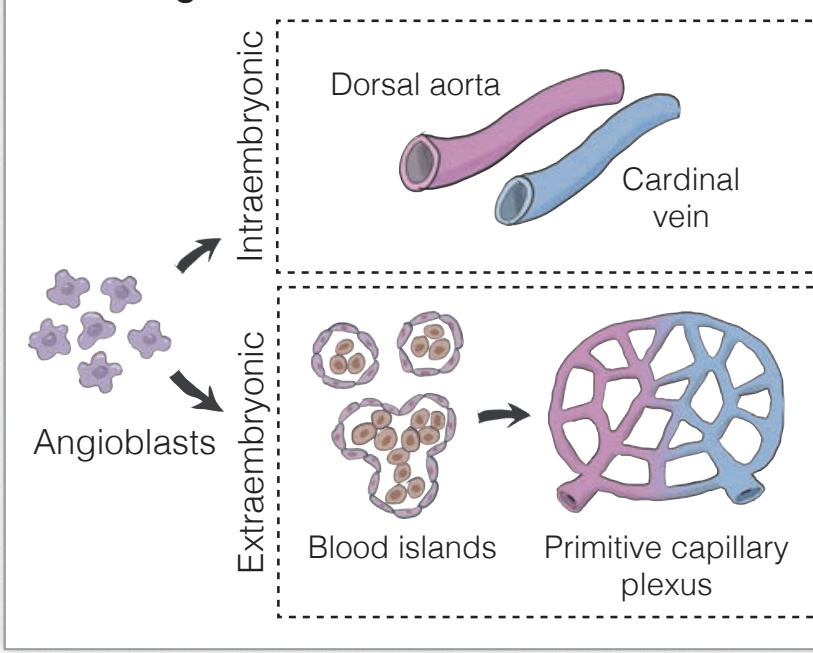

b Angiogenesis
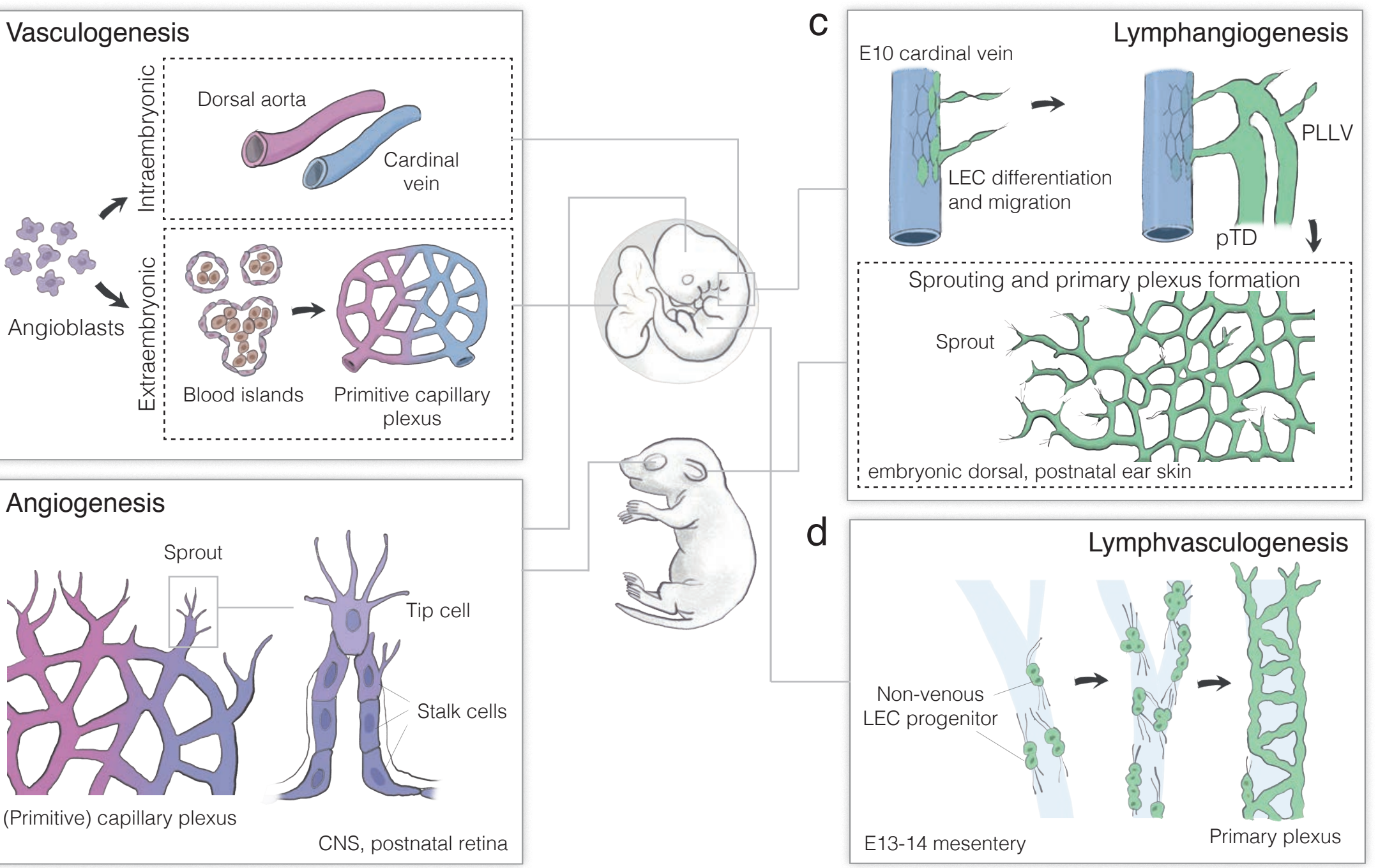
Figure 4

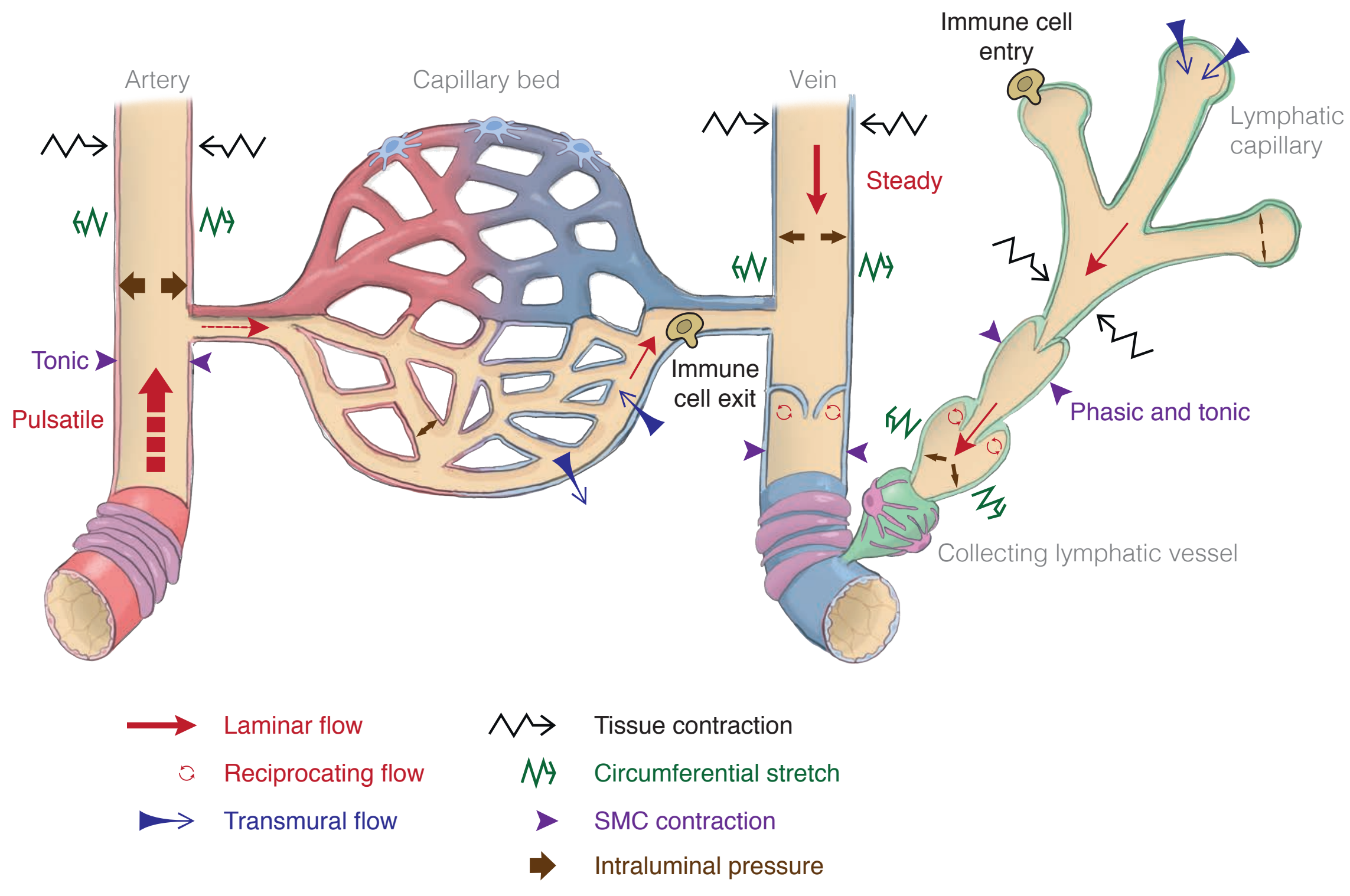




\section{Figure 3}

Pre-exisiting ECs expand the vascular

Clonal expansion of specialised ECs generates high endothelial venules and capillaries (lymph node)

Integration of circulatory or vessel wall-resident progenitors

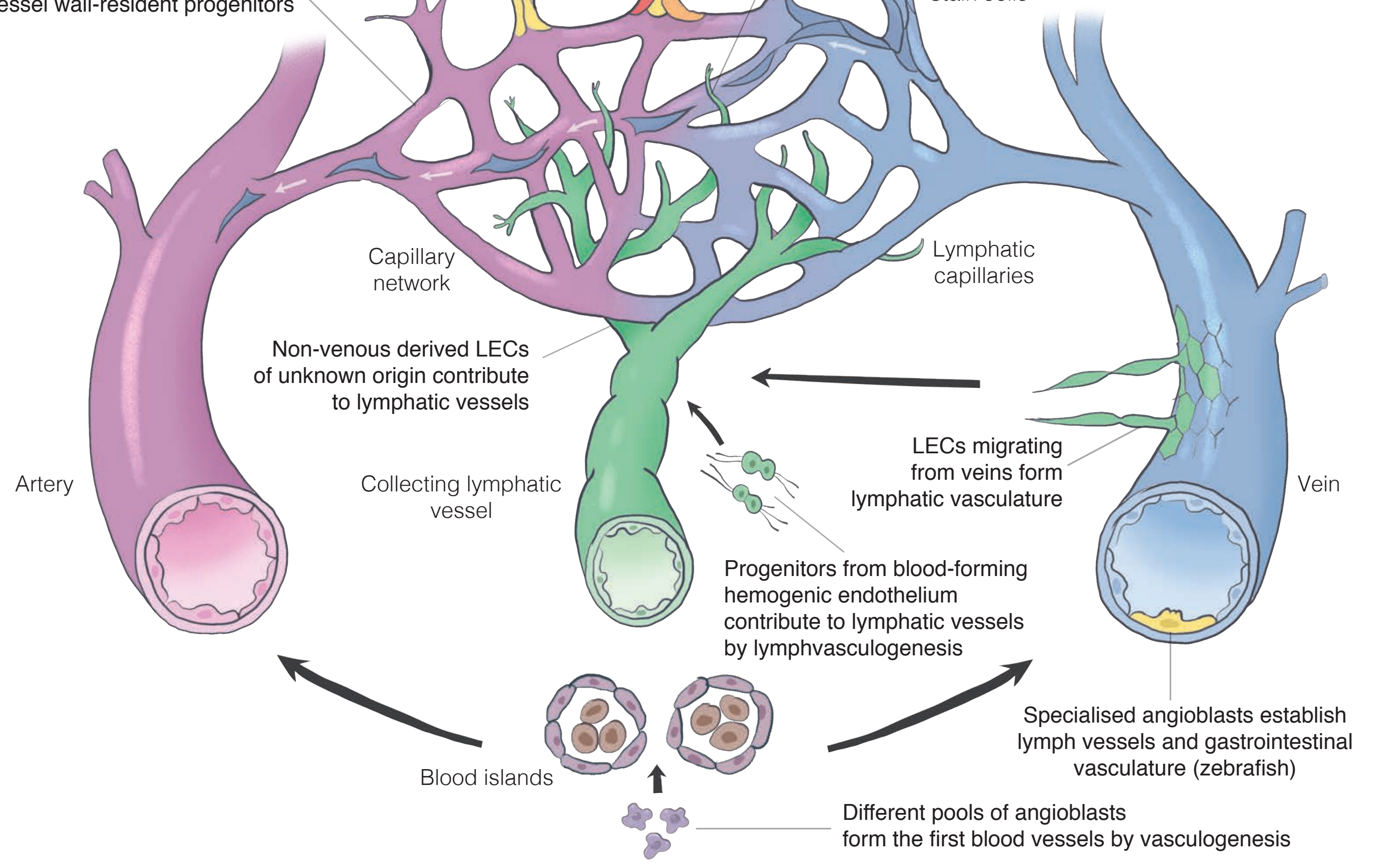




\section{Tables}

Table 1 | Examples of organ-specific endothelial specialization

\begin{tabular}{|c|c|c|c|c|c|c|}
\hline $\begin{array}{c}\text { Type of } \\
\text { ECs }\end{array}$ & Location & $\begin{array}{l}\text { EC phenotypes / } \\
\text { characteristics }\end{array}$ & Specialized function & $\begin{array}{c}\text { Molecular } \\
\text { markers }\end{array}$ & $\begin{array}{c}\text { Mechanism(s) of } \\
\text { specialization }\end{array}$ & *Ref. \\
\hline $\begin{array}{l}\text { Blood- } \\
\text { brain-barrier } \\
\text { (BBB) ECs }\end{array}$ & $\begin{array}{l}\text { Central } \\
\text { nervous } \\
\text { system }\end{array}$ & $\begin{array}{l}\text { - Continuous } \\
\text { - Specialized } \\
\text { tight junctions } \\
\text { (occludins, } \\
\text { claudins, JAMs) } \\
\text { - Inhibition of } \\
\text { fenestrae, } \\
\text { pinocytosis, } \\
\text { bulk-flow } \\
\text { transcytosis } \\
\text { - Suppression of } \\
\text { leukocyte } \\
\text { adhesion }\end{array}$ & $\begin{array}{l}\text { - Highly selective } \\
\text { barrier to protect } \\
\text { neurons from toxic } \\
\text { molecules, cells, and } \\
\text { pathogens } \\
\text { - Specialized for } \\
\text { efficient glucose } \\
\text { transport to the brain } \\
\text { - Substrate-specific } \\
\text { transporters for } \\
\text { selective transfer } \\
\text { (nutrients, } \\
\text { metabolites) }\end{array}$ & $\begin{array}{l}\text { - MFSD2a } \\
\text { - GLUT1 } \\
\text { - SLC7A5, } \\
\text { others }\end{array}$ & $\begin{array}{l}\text { Pericyte- } \\
\text { derived signals } \\
\text { induce and } \\
\text { maintain BBB } \\
\text { properties and } \\
\text { integrity }\end{array}$ & $1-5$ \\
\hline $\begin{array}{l}\text { Myocardial } \\
\text { capillaries }\end{array}$ & Heart & $\begin{array}{l}\text { - Continuous } \\
\text { - Ratio of ECs to } \\
\text { cardiomyocytes } \\
\text { 3:1 } \\
\text { - Distance EC to } \\
\text { cardiomyocyte } \\
1 \mu \mathrm{m}\end{array}$ & $\begin{array}{l}\text { - Preferential fatty acid } \\
\text { uptake and transfer } \\
\text { of FA to the } \\
\text { myocardium } \\
\text { - Support } \\
\text { cardiomyocyte } \\
\text { survival }\end{array}$ & $\begin{array}{l}\text { - } \text { CD36 } \\
\text { - } \text { LPL } \\
\text { - PPARG }\end{array}$ & $\begin{array}{l}- \text { MEOX/TCF15 } \\
\text { induce FA } \\
\text { transport genes } \\
\text { - VEGFB } \\
\text { increases FA } \\
\text { transfer and } \\
\text { vessel growth }\end{array}$ & $6-8$ \\
\hline $\begin{array}{l}\text { Pulmonary } \\
\text { capillaries }\end{array}$ & Lung & $\begin{array}{l}\text { - Dense network } \\
\text { through which } \\
\text { blood flows as a } \\
\text { sheet } \\
\text { - Extremely thin } \\
\text { blood-air- } \\
\text { barrier } \\
\text { - Large number } \\
\text { of caveolae }\end{array}$ & $\begin{array}{l}\text { Specialized for } \\
\text { efficient gas } \\
\text { exchange at the } \\
\text { blood-air-barrier }\end{array}$ & $\begin{array}{l}\cdot \text { ACE } \\
- \text { ALCAM/ } \\
\text { CD166 }\end{array}$ & Unknown & $\begin{array}{l}\text { Review } \\
\text { ed in }\end{array}$ \\
\hline $\begin{array}{l}\text { Liver } \\
\text { sinusoidal } \\
\text { ECs }\end{array}$ & Liver & $\begin{array}{l}\text { - Discontinuous } \\
\text { - Fenestrated } \\
\text { (pore size 100- } \\
200 \mathrm{~nm} \text {, non- } \\
\text { diaphragmed) } \\
\text { - Fenestrae } \\
\text { arranged as } \\
\text { sieve plates } \\
\text { - Lack organized } \\
\text { basement } \\
\text { membrane }\end{array}$ & $\begin{array}{l}\text { - Dynamic filter for } \\
\text { fluids, solutes, } \\
\text { particles } \\
\text { - Clearance of soluble } \\
\text { waste } \\
\text { macromolecules via } \\
\text { receptor-mediated } \\
\text { endocytosis } \\
\text { - Hepatic immune } \\
\text { tolerance } \\
\text { - Control hepatocyte } \\
\text { proliferation }\end{array}$ & $\begin{array}{l}\text { - Stabilin } 1 \\
\text { - Stabilin } 2 \\
\text { - HGF } \\
\text { - WNT2 }\end{array}$ & $\begin{array}{l}\text { Hepatocyte- } \\
\text { derived VEGF } \\
\text { and autocrine } \\
\text { WNT2 promote } \\
\text { differentiation } \\
\text { of LSECs }\end{array}$ & $\begin{array}{l}10,11 \\
\text { Review } \\
\text { in } 9\end{array}$ \\
\hline $\begin{array}{l}\text { Glomerular } \\
\text { ECs }\end{array}$ & Kidney & $\begin{array}{l}\text { - Fenestrated } \\
\text { (pore size } 60-80 \\
\text { nm) } \\
\text { - Fenestrae cover } \\
20 \% \text { of EC } \\
\end{array}$ & $\begin{array}{l}\text { - Size- and charge- } \\
\text { selective filtration } \\
\text { barrier } \\
\text { - Vasomotor tone } \\
\text { control }\end{array}$ & N.D. & $\begin{array}{l}\text { - Podocyte- } \\
\text { derived VEGF } \\
\text { induces and } \\
\text { maintains } \\
\text { fenestrations } \\
\end{array}$ & 12 \\
\hline
\end{tabular}




\begin{tabular}{|c|c|c|c|c|c|c|}
\hline & & $\begin{array}{l}\text { surface } \\
\text { - Thick } \\
\text { endothelial } \\
\text { glycocalyx (60 } \\
\text { to } 300 \mathrm{~nm})\end{array}$ & & & & \\
\hline Type H ECs & $\begin{array}{l}\text { Metaphysis / } \\
\text { endosteum of } \\
\text { long bones }\end{array}$ & $\begin{array}{l}\text { - Organized as } \\
\text { interconnected } \\
\text { vessel columns } \\
\text { - Direct arterial } \\
\text { supply } \\
\text { - Well } \\
\text { oxygenated } \\
\text { - Associated with } \\
\text { osteoprogenitor } \\
\text { cells }\end{array}$ & $\begin{array}{l}\text { - Mediate bone } \\
\text { angiogenesis } \\
\text { - Control bone- } \\
\text { forming } \\
\text { osteoprogenitor cells } \\
\text { through the release of } \\
\text { osteogenic factors }\end{array}$ & $\begin{array}{l}\text { - High } \\
\text { levels of } \\
\text { PECAM / } \\
\text { EMCN }\end{array}$ & $\begin{array}{l}\text { - HIF1- and } \\
\text { DLL4/Notch } \\
\text { signalling } \\
\text { induces type H } \\
\text { ECs }\end{array}$ & 13 \\
\hline Type L ECs & $\begin{array}{l}\text { Diaphysis of } \\
\text { long bone } \\
\text { (bone marrow) }\end{array}$ & $\begin{array}{l}\text { - Highly } \\
\text { branched } \\
\text { sinusoidal } \\
\text { network } \\
\text { - Connect to the } \\
\text { central vein } \\
\text { - Hypoxic } \\
\text { - Surrounded by } \\
\text { densely } \\
\text { hematopoietic } \\
\text { cells } \\
\end{array}$ & $\begin{array}{l}\text { - Interaction with cells } \\
\text { of the hematopoietic } \\
\text { system } \\
\text { - Niche for } \\
\text { hematopoietic stem } \\
\text { cells }\end{array}$ & $\begin{array}{l}\text { - Low levels } \\
\text { of } \\
\text { PECAM / } \\
\text { EMCN }\end{array}$ & $\begin{array}{l}\text { - Emerges from } \\
\text { type H ECs }\end{array}$ & 13 \\
\hline $\begin{array}{l}\text { High } \\
\text { endothelial } \\
\text { venule ECs }\end{array}$ & $\begin{array}{l}\text { Lymph nodes } \\
\text { and secondary } \\
\text { lymphoid } \\
\text { organs (except } \\
\text { spleen); } \\
\text { non-lymphoid } \\
\text { organs during } \\
\text { chronic } \\
\text { inflammation } \\
\text { and cancer }\end{array}$ & $\begin{array}{l}\text { - Plump } \\
\text { appearance } \\
\text { - Support } \\
\text { tethering, } \\
\text { rolling and } \\
\text { transmigration } \\
\text { of immune cells } \\
\text { - Clonal } \\
\text { expansion } \\
\text { during } \\
\text { inflammation- } \\
\text { induced } \\
\text { expansion of } \\
\text { the lymph node } \\
\text { vasculature }\end{array}$ & $\begin{array}{l}\text { - Control homing and } \\
\text { entry of lymphocytes } \\
\text { and other immune } \\
\text { cells (including } \\
\text { precursors of } \\
\text { conventional DCs } \\
\text { and NK cells) }\end{array}$ & $\begin{array}{l}\text { HEV } \\
\text { sialomucins } \\
\text { (addressins), } \\
\text { with 6- } \\
\text { sulpho sialyl } \\
\text { Lewis X on } \\
\text { O- and N- } \\
\text { clycans, and } \\
\text { molecules } \\
\text { involved in } \\
\text { their } \\
\text { synthesis } \\
\text { (e.g. } \\
\text { GLYCAM1, } \\
\text { FUT7), } \\
\text { CD63, } \\
\text { CCL21 }\end{array}$ & $\begin{array}{l}\mathrm{CD}_{11 \mathrm{c}^{+} \mathrm{DC}} \\
\text { derived } \\
\text { lymphotoxin } \\
\text { regulates HEV } \\
\text { phenotype and } \\
\text { function in LN }\end{array}$ & $\begin{array}{l}14 \text { and } \\
\text { rev. in } \\
15\end{array}$ \\
\hline $\begin{array}{l}\text { Lymph node } \\
\text { LECs: } \\
\text { - Subcap. } \\
\text { sinus } \\
\text { (SCS) } \\
\text { - Medullary } \\
\text { sinus } \\
\text { (MS) } \\
\text { - Cortical } \\
\text { sinus (CS) }\end{array}$ & Lymph nodes & $\begin{array}{l}\text { Different } \\
\text { phenotypes in } \\
\text { different parts } \\
\text { of the LN }\end{array}$ & $\begin{array}{l}\text { - Control size-selective } \\
\text { entry of antigens } \\
\text { (SCS) } \\
\text { - DC entry (SCS) } \\
\text { - Lymphocyte egress } \\
\text { (MS/CS) } \\
\text { - Antigen presentation } \\
\text { and induction of } \\
\text { peripheral immune } \\
\text { tolerance }\end{array}$ & $\begin{array}{l}\text { CCL1 } \\
\text { (SCS); } \\
\text { CCRL1 } \\
\text { (ceiling of } \\
\text { SCS); } \\
\text { LYVE1 (all } \\
\text { but ceiling } \\
\text { of SCS), } \\
\text { PLVAP, } \\
\text { S1P, PD-L1 }\end{array}$ & $\begin{array}{l}\text { VEGFC regulates } \\
\text { growth }\end{array}$ & $\begin{array}{l}14 \text { and } \\
\text { rev. } \\
\text { in }^{15,16}\end{array}$ \\
\hline Lacteal ECs & $\begin{array}{l}\text { Villi of the } \\
\text { small intestine }\end{array}$ & $\begin{array}{l}\text { - Lymphatic } \\
\text { capillary-type }\end{array}$ & $\begin{array}{l}\text { - Absorption of dietary } \\
\text { fats (chylomicrons) }\end{array}$ & $\begin{array}{l}\text { - Lymphatic } \\
\text { capillary }\end{array}$ & $\begin{array}{l}\text { - VEGFC and } \\
\text { DLL4 maintain }\end{array}$ & 17,18 \\
\hline
\end{tabular}




\begin{tabular}{|c|c|c|c|c|c|c|}
\hline & & $\begin{array}{l}\text { EC } \\
\text { - Combination of } \\
\text { zipper and } \\
\text { button-like } \\
\text { junctions } \\
\text { - Continuous } \\
\text { (low-level) } \\
\text { proliferation } \\
\text { and sprouting } \\
\end{array}$ & $\begin{array}{l}\text { and fat-soluble } \\
\text { vitamins } \\
\text { - Entry for tissue- } \\
\text { derived DCs to } \\
\text { mesenteric lymph } \\
\text { nodes allows } \\
\text { induction of oral } \\
\text { tolerance }\end{array}$ & $\begin{array}{l}\text { markers } \\
\text { including } \\
\text { LYVE1 } \\
\text { and } \\
\text { CCL21 }\end{array}$ & lacteals & \\
\hline $\begin{array}{l}\text { Meningeal } \\
\text { LECs }\end{array}$ & Meninges & $\begin{array}{l}\text { Lymphatic } \\
\text { capillary-type } \\
\text { EC }\end{array}$ & $\begin{array}{l}\text { - Drainage of } \\
\text { cerebrospinal fluid } \\
\text { - Delivery of antigens } \\
\text { and immune cells to } \\
\text { cervical lymph nodes }\end{array}$ & $\begin{array}{l}\text { - Lymphatic } \\
\text { capillary } \\
\text { markers, } \\
\text { including } \\
\text { LYVE1 } \\
\text { and } \\
\text { CCL21 }\end{array}$ & $\begin{array}{l}\text { VEGFC } \\
\text { regulates } \\
\text { growth }\end{array}$ & 19,20 \\
\hline $\begin{array}{l}\text { Schlemm's } \\
\text { canal EC }\end{array}$ & Eye & $\begin{array}{l}\text { - Circular } \\
\text { 'lymphatic-like' } \\
\text { vessel }\end{array}$ & $\begin{array}{l}\text { Drainage of aqueous } \\
\text { humour in between } \\
\text { the lens and the } \\
\text { cornea }\end{array}$ & $\begin{array}{l}- \text { LEC } \\
\text { markers } \\
\text { except for } \\
\text { PDPN and } \\
\text { LYVE1 }\end{array}$ & $\begin{array}{l}\text { - Forms by } \\
\text { postnatal } \\
\text { migration of } \\
\text { venous-derived } \\
\text { ECs } \\
\text { - VEGFC and } \\
\text { ANG/TIE2 } \\
\text { regulate growth }\end{array}$ & $21-23$ \\
\hline
\end{tabular}

*Please see supplementary information for references 
Table 2 | Summary of organ- and vessel type-specific vascular abnormalities and their underlying mutations

\begin{tabular}{|c|c|c|c|c|c|c|}
\hline $\begin{array}{c}\text { Affected } \\
\text { vessel type }\end{array}$ & $\begin{array}{c}\text { Main affected } \\
\operatorname{organ}(\mathbf{s})\end{array}$ & Disease & $\begin{array}{c}\text { Disease manifestation } \\
\text { and proposed mechanism }\end{array}$ & Gene & $\begin{array}{c}\text { Type of } \\
\text { mutation }\end{array}$ & Ref. \\
\hline Vein & $\begin{array}{l}\text { Mucosa, skin, } \\
\text { muscle }\end{array}$ & $\begin{array}{l}\text { Cutaneomucosal } \\
\text { VM (VMCM) }\end{array}$ & $\begin{array}{l}\text { Dilated veins with thick } \\
\text { fibrotic walls and irregular } \\
\text { SMC coverage; defective } \\
\text { communication between } \\
\text { EC and SMC }\end{array}$ & TIE2 & $\begin{array}{l}\text { Inherited }+ \\
\text { somatic } \\
\text { (second-hit) } \\
\text { activating }\end{array}$ & 24 \\
\hline Vein & $\begin{array}{l}\text { Skin, subcutis; } \\
\text { also mucosa, } \\
\text { muscle, joints, } \\
\text { gastrointestnal } \\
\text { tract, lung, } \\
\text { brain }\end{array}$ & Sporadic VM & $\begin{array}{l}\text { Dilated veins with thick } \\
\text { fibrotic walls and irregular } \\
\text { SMC coverage; defective } \\
\text { communication between } \\
\text { EC and SMC }\end{array}$ & TIE2 & $\begin{array}{l}\text { Somatic } \\
\text { activating }\end{array}$ & 25 \\
\hline Vein & $\begin{array}{l}\text { Subcutis, } \\
\text { mucosa, } \\
\text { muscle, joints }\end{array}$ & Sporadic VM & $\begin{array}{l}\text { Dilated or interconnected } \\
\text { veins with thick fibrotic } \\
\text { walls and irregular SMC } \\
\text { coverage; defective } \\
\text { communication between } \\
\text { EC and SMC }\end{array}$ & $P I K 3 C A$ & $\begin{array}{l}\text { Somatic } \\
\text { activating }\end{array}$ & $26-28$ \\
\hline Vein & $\begin{array}{l}\text { Skin (palms and } \\
\text { soles), } \\
\text { gastrointestinal } \\
\text { tract }\end{array}$ & $\begin{array}{l}\text { Blue rubber bleb } \\
\text { nevus syndrome } \\
(\mathrm{BRBN})\end{array}$ & $\begin{array}{l}\text { Dilated veins with thick } \\
\text { fibrotic walls and irregular } \\
\text { SMC coverage, } \\
\text { hemorrhaging; defective } \\
\text { communication between } \\
\text { EC and SMC }\end{array}$ & TIE2 & $\begin{array}{l}\text { Two somatic } \\
\text { activating } \\
\text { mutations on } \\
\text { the same } \\
\text { allele }\end{array}$ & 29 \\
\hline Vein & $\begin{array}{l}\text { Skin, subcutis } \\
\text { in extremeties }\end{array}$ & $\begin{array}{l}\text { Glomeruvenous } \\
\text { malformation } \\
(\mathrm{GVN})\end{array}$ & $\begin{array}{l}\text { Undifferentiated SMCs } \\
\text { (glomus cells) around } \\
\text { distended vein-like } \\
\text { channels; defect in SMC } \\
\text { differentiation leading to } \\
\text { defective vessel maturation }\end{array}$ & $G L M N$ & $\begin{array}{l}\text { Inherited }+ \\
\text { somatic } \\
\text { (second-hit) } \\
\text { inactivating }\end{array}$ & 30 \\
\hline $\begin{array}{l}\text { Lymphatic } \\
\text { vessel }\end{array}$ & $\begin{array}{l}\text { Any tissue } \\
\text { except brain }\end{array}$ & $\begin{array}{l}\text { Lymphatic } \\
\text { malformation } \\
(\mathrm{LM})\end{array}$ & $\begin{array}{l}\text { Malformed, dilated and } \\
\text { dysfunctional lymphatic } \\
\text { channels (microcystic), or } \\
\text { large cyst-like cavities } \\
\text { containing lymph } \\
\text { (macrocystic) }\end{array}$ & $P I K 3 C A$ & $\begin{array}{l}\text { Somatic } \\
\text { activating }\end{array}$ & 31 \\
\hline $\begin{array}{l}\text { Lymphatic } \\
\text { vessel } \\
\text { (capillary) }\end{array}$ & $\begin{array}{l}\text { Feet (up to the } \\
\text { knees) }\end{array}$ & $\begin{array}{l}\text { Milroy disease } \\
\text { (primary } \\
\text { lymphedema) }\end{array}$ & $\begin{array}{l}\text { Swelling of lower limbs; } \\
\text { lack of lymphatic drainage } \\
\text { due to hypoplasia or } \\
\text { dysfunction of lymphatic } \\
\text { capillaries }\end{array}$ & VEGFR3 & $\begin{array}{l}\text { Inherited } \\
\text { heterozygous } \\
\text { inactivating }\end{array}$ & 32 \\
\hline $\begin{array}{l}\text { Lymphatic } \\
\text { vessel } \\
\text { (collecting) }\end{array}$ & Lower limbs & $\begin{array}{l}\text { Lymphedema } \\
\text { distichiasis (LD; } \\
\text { primary } \\
\text { lymphedema) }\end{array}$ & $\begin{array}{l}\text { Swelling of lower limbs; } \\
\text { retrograde lymph flow due } \\
\text { to lack of lymphatic valves }\end{array}$ & $F O X C 2$ & $\begin{array}{l}\text { Inherited } \\
\text { heterozygous } \\
\text { inactivating }\end{array}$ & 33,34 \\
\hline Mixed & $\begin{array}{l}\text { CM: skin; } \\
\text { AVM: CNS, } \\
\text { extremities }\end{array}$ & $\begin{array}{l}\text { Capillary } \\
\text { malformation- } \\
\text { arteriovenous } \\
\text { malformation } \\
(\mathrm{CM}-\mathrm{AVM}) \\
\end{array}$ & $\begin{array}{l}\text { Overactivation of } \\
\text { RAS/MAPK signalling } \\
\text { leading to abnormal vessel } \\
\text { development }\end{array}$ & $R A S A 1$ & $\begin{array}{l}\text { Inherited } \\
\text { heterozygous } \\
\text { (+ somatic } \\
\text { (second-hit) } \\
\text { inactivating }\end{array}$ & 35 \\
\hline
\end{tabular}




\begin{tabular}{|c|c|c|c|c|c|c|}
\hline Mixed & $\begin{array}{l}\text { Telangiectasias: } \\
\text { skin, mucosa; } \\
\text { AVM: lung, } \\
\text { liver, brain }\end{array}$ & $\begin{array}{l}\text { Hereditary } \\
\text { hemorrhagic } \\
\text { telangiectasia } \\
\text { (HHT) }\end{array}$ & $\begin{array}{l}\text { Dilatation of post-capillary } \\
\text { venules with excessive } \\
\text { layers of SMCs. AVMs } \\
\text { due to defects in flow- } \\
\text { induced vascular } \\
\text { stabilization }\end{array}$ & $\begin{array}{l}\text { ENG, } \\
\text { ALK1, } \\
\text { SMAD4 }\end{array}$ & $\begin{array}{l}\text { Inherited } \\
\text { heterozygous } \\
\text { inactivating }\end{array}$ & $36-38$ \\
\hline $\begin{array}{l}\text { Mixed } \\
\text { (capillary- } \\
\text { venous) }\end{array}$ & $\mathrm{CNS}$ & $\begin{array}{l}\text { Cerebral } \\
\text { cavernous } \\
\text { malformation } \\
(\mathrm{CCM})\end{array}$ & $\begin{array}{l}\text { Dilated blood vessels with } \\
\text { multiple caverns; defect in } \\
\text { EC cell-cell junctions }\end{array}$ & $C C M 1-3$ & 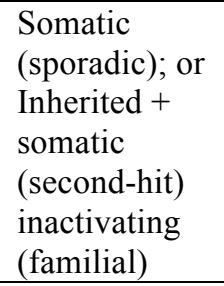 & $39-42$ \\
\hline $\begin{array}{l}\text { Schlemm's } \\
\text { canal }\end{array}$ & Eye & $\begin{array}{l}\text { Primary } \\
\text { congenital } \\
\text { glaucoma }\end{array}$ & $\begin{array}{l}\text { Hypoplasia of Schlemm's } \\
\text { canal }\end{array}$ & TIE2 & $\begin{array}{l}\text { Inherited } \\
\text { heterozygous } \\
\text { inactivating } \\
\text { (haploinsuffic } \\
\text { iency) }\end{array}$ & 43 \\
\hline
\end{tabular}

*Please see supplementary information for references 


\section{Supplementary information}

\section{References for tables}

1 Armulik, A. et al. Pericytes regulate the blood-brain barrier. Nature 468, 557-561, (2010).

2 Ben-Zvi, A. et al. Mfsd2a is critical for the formation and function of the blood-brain barrier. Nature 509, 507-511, (2014).

3 Nguyen, L. N. et al. Mfsd2a is a transporter for the essential omega-3 fatty acid docosahexaenoic acid. Nature 509, 503-506, (2014).

4 Zhao, Z., Nelson, A. R., Betsholtz, C. \& Zlokovic, B. V. Establishment and Dysfunction of the Blood-Brain Barrier. Cell 163, 1064-1078, (2015).

5 Tarlungeanu, D. C. et al. Impaired Amino Acid Transport at the Blood Brain Barrier Is a Cause of Autism Spectrum Disorder. Cell 167, 1481-1494.e1418, d (2016).

6 Hagberg, C. E. et al. Vascular endothelial growth factor B controls endothelial fatty acid uptake. Nature 464, 917-921, (2010).

$7 \quad$ Kivela, R. et al. VEGF-B-induced vascular growth leads to metabolic reprogramming and ischemia resistance in the heart. EMBO molecular medicine 6, 307-321, (2014).

8 Dijkstra, M. H. et al. Lack of cardiac and high-fat diet induced metabolic phenotypes in two independent strains of Vegf-b knockout mice. Scientific reports 4, 6238, (2014).

9 Aird, W. C. Phenotypic heterogeneity of the endothelium: II. Representative vascular beds. Circulation research 100, 174-190, (2007).

10 LeCouter, J. et al. Angiogenesis-independent endothelial protection of liver: role of VEGFR-1. Science (New York, N.Y.) 299, 890-893, (2003).

11 Klein, D. et al. Wnt2 acts as a cell type-specific, autocrine growth factor in rat hepatic sinusoidal endothelial cells cross-stimulating the VEGF pathway. Hepatology (Baltimore, Md.) 47, 1018-1031, (2008).

12 Kamba, T. et al. VEGF-dependent plasticity of fenestrated capillaries in the normal adult microvasculature. Am J Physiol Heart Circ Physiol 290, H560-576, (2006).

13 Kusumbe, A. P., Ramasamy, S. K. \& Adams, R. H. Coupling of angiogenesis and osteogenesis by a specific vessel subtype in bone. Nature 507, 323-328, (2014).

14 Lee, M. et al. Transcriptional programs of lymphoid tissue capillary and high endothelium reveal control mechanisms for lymphocyte homing. Nat Immunol 15, 982995, (2014).

15 Girard, J. P., Moussion, C. \& Forster, R. HEVs, lymphatics and homeostatic immune cell trafficking in lymph nodes. Nat Rev Immunol 12, 762-773, (2012).

16 Ulvmar, M. H. \& Makinen, T. Heterogeneity in the lymphatic vascular system and its origin. Cardiovasc Res 111, 310-321, (2016).

17 Bernier-Latmani, J. et al. DLL4 promotes continuous adult intestinal lacteal regeneration and dietary fat transport. $J$ Clin Invest 125, 4572-4586, (2015).

18 Nurmi, H. et al. VEGF-C is required for intestinal lymphatic vessel maintenance and lipid absorption. EMBO molecular medicine 7, 1418-1425, (2015).

19 Aspelund, A. et al. A dural lymphatic vascular system that drains brain interstitial fluid and macromolecules. J Exp Med 212, 991-999, (2015).

20 Louveau, A. et al. Structural and functional features of central nervous system lymphatic vessels. Nature 523, 337-341, (2015). 
21 Aspelund, A. et al. The Schlemm's canal is a VEGF-C/VEGFR-3-responsive lymphaticlike vessel. J Clin Invest 124, 3975-3986, (2014).

22 Park, D. Y. et al. Lymphatic regulator PROX1 determines Schlemm's canal integrity and identity. J Clin Invest 124, 3960-3974, (2014).

23 Kizhatil, K., Ryan, M., Marchant, J. K., Henrich, S. \& John, S. W. Schlemm's canal is a unique vessel with a combination of blood vascular and lymphatic phenotypes that forms by a novel developmental process. PLoS Biol 12, e1001912, (2014).

24 Limaye, N. et al. Somatic mutations in angiopoietin receptor gene TEK cause solitary and multiple sporadic venous malformations. Nat Genet 41, 118-124, (2009).

25 Vikkula, M. et al. Vascular dysmorphogenesis caused by an activating mutation in the receptor tyrosine kinase TIE2. Cell 87, 1181-1190 (1996).

26 Limaye, N. et al. Somatic Activating PIK3CA Mutations Cause Venous Malformation. Am J Hum Genet 97, 914-921, (2015).

27 Castel, P. et al. Somatic PIK3CA mutations as a driver of sporadic venous malformations. Sci Transl Med 8, 332ra342, (2016).

28 Castillo, S. D. et al. Somatic activating mutations in Pik3ca cause sporadic venous malformations in mice and humans. Sci Transl Med 8, 332ra343, (2016).

29 Soblet, J. et al. Blue Rubber Bleb Nevus (BRBN) Syndrome Is Caused by Somatic TEK (TIE2) Mutations. J Invest Dermatol 137, 207-216, (2017).

30 Brouillard, P. et al. Mutations in a novel factor, glomulin, are responsible for glomuvenous malformations ("glomangiomas"). Am J Hum Genet 70, 866-874, (2002).

31 Luks, V. L. et al. Lymphatic and other vascular malformative/overgrowth disorders are caused by somatic mutations in PIK3CA. J Pediatr 166, 1048-1054 e1041-1045, (2015).

32 Karkkainen, M. J. et al. Missense mutations interfere with VEGFR-3 signalling in primary lymphoedema. Nat Genet 25, 153-159, (2000).

33 Finegold, D. N. et al. Truncating mutations in FOXC2 cause multiple lymphedema syndromes. Hum Mol Genet 10, 1185-1189 (2001).

34 Fang, J. et al. Mutations in FOXC2 (MFH-1), a forkhead family transcription factor, are responsible for the hereditary lymphedema-distichiasis syndrome. Am J Hum Genet 67, 1382-1388, (2000).

35 Eerola, I. et al. Capillary malformation-arteriovenous malformation, a new clinical and genetic disorder caused by RASA1 mutations. Am J Hum Genet 73, 1240-1249, (2003).

36 Gallione, C. J. et al. A combined syndrome of juvenile polyposis and hereditary haemorrhagic telangiectasia associated with mutations in MADH4 (SMAD4). Lancet 363, 852-859, (2004).

37 Johnson, D. W. et al. Mutations in the activin receptor-like kinase 1 gene in hereditary haemorrhagic telangiectasia type 2. Nat Genet 13, 189-195, (1996).

38 McAllister, K. A. et al. Endoglin, a TGF-beta binding protein of endothelial cells, is the gene for hereditary haemorrhagic telangiectasia type 1. Nat Genet 8, 345-351, (1994).

39 Sahoo, T. et al. Mutations in the gene encoding KRIT1, a Krev-1/rapla binding protein, cause cerebral cavernous malformations (CCM1). Hum Mol Genet 8, 2325-2333 (1999).

40 Liquori, C. L. et al. Mutations in a gene encoding a novel protein containing a phosphotyrosine-binding domain cause type 2 cerebral cavernous malformations. Am J Hum Genet 73, 1459-1464, (2003).

41 Laberge-le Couteulx, S. et al. Truncating mutations in CCM1, encoding KRIT1, cause hereditary cavernous angiomas. Nat Genet 23, 189-193, (1999). 
42 Bergametti, F. et al. Mutations within the programmed cell death 10 gene cause cerebral cavernous malformations. Am J Hum Genet 76, 42-51, (2005).

43 Souma, T. et al. Angiopoietin receptor TEK mutations underlie primary congenital glaucoma with variable expressivity. J Clin Invest 126, 2575-2587, (2016). 